\title{
Directional Guidance of Oligodendroglial Migration by Class 3 Semaphorins and Netrin-1
}

\author{
Nathalie Spassky, ${ }^{1 *}$ Fernando de Castro, ${ }^{1,3 *}$ Barbara Le Bras, ${ }^{1 *}$ Katharina Heydon, ${ }^{1}$ \\ Françoise Quéraud-LeSaux, ${ }^{1}$ Evelyne Bloch-Gallego, ${ }^{2}$ Alain Chédotal, ${ }^{2}$ Bernard Zalc, ${ }^{1}$ and \\ Jean-Léon Thomas ${ }^{1}$ \\ ${ }^{1}$ Biologie des Interactions Neurones, Glie Institut National de la Santé et de la Recherche Médicale (INSERM) U-495 and \\ 2INSERM U-106, Université Pierre et Marie Curie, IFR des Neurosciences, Hôpital de la Salpêtrière, 75651 Paris, France, \\ and ${ }^{3}$ Neurobiología, Department de Investigación, Hospital Ramón y Cajal, E-28034 Madrid, Spain
}

\begin{abstract}
Oligodendrocytes, the myelin-forming cells of the CNS, are generated from multiple foci distributed along the developing neural tube. Little is known about the endogenous guidance cues controlling the migration of oligodendrocyte precursor cells (OPCs) from their site of emergence toward their final destination, mainly the future white matter tracts. During embryonic development, the optic nerve is populated by OPCs originating in the diencephalon that migrate from the chiasm toward the retina. Here we show that OPCs migrating into the embryonic optic nerve express the semaphorin receptors neuropilin-1 and -2 , as well as deleted in colorectal cancer (DCC) and, to a lesser extend unc5 $\mathrm{H} 1$, two of the netrin-1 receptors. Using a functional migration assay, we provide evi-
\end{abstract}

dence that Sema 3A and netrin-1 exert opposite chemotactic effects, repulsive or attractive, respectively, on embryonic OPCs. In addition, we show that Sema $3 F$ has a dual effect, chemoattractive and mitogenic on embryonic OPCs. The localization of cells expressing Sema $3 \mathrm{~A}$, Sema $3 \mathrm{~F}$, and netrin-1 is consistent with a role for these ligands in the migration of OPCs in the embryonic optic nerve. Altogether, our results suggest that the migration of OPCs in the embryonic optic nerve is modulated by a balance of effects mediated by members of the semaphorin and netrin families.

Key words: cell migration; class 3 semaphorins; multiple sclerosis; myelin; netrin-1; oligodendrocyte; optic nerve
During embryonic development, oligodendrocytes colonize the CNS from multiple ventricular foci (Yu et al., 1994; Ono et al., 1997; Spassky et al., 1998). Their migration pathways toward the presumptive white matter tracts and the gray matter have been analyzed, notably in birds in which long distance migrations have been described in the forebrain (Ono et al., 1997; Olivier et al., 2001). The molecular mechanisms guiding the oligodendrocyte precursor cells (OPCs) during their migration remain poorly understood. Contact-mediated cues have first been implicated, notably cell adhesion molecules and components of the extracellular matrix such as integrins (Payne and Lemmon, 1993; Milner and Ffrench-Constant, 1994), the polysialylated form of neural cell adhesion molecule (NCAM) (Wang et al., 1994), and

\footnotetext{
Received Sept. 26, 2001; revised April 15, 2002; accepted April 17, 2002.

This work was supported by Institut National de la Santé et de la Recherche Médicale and by grants from the European Community (QLG3-CT-2000-01556), the Association de Recherche sur la Sclérose en Plaques, and Association pour la Recherche coutre le Cancer (5778 to J.-L.T., 5249 to A.C., and 9954 to E.B.-G.). F.D. had a Traveling Fellowship from "Development - The Company of Biologists, Ltd." (Cambridge, UK). N.S. was a fellow of the Ministère de l'Education Nationale et de la Recherche and Fondation pour la Recherche Médicale. B.L.B. is a fellow of the Ministère de l' Education Nationale et de la Recherche. We thank Dr. M. Tessier-Lavigne for generously allowing us to use the neuropilin-2-lacZ knock-in mice and for the gift of $\mathrm{DCC}$ and $u n c 5 H 1,2,3$ plasmids, as well as Drs. A. Frankfurter, M. Fabre, N. Thomasset, and J. Trotter for providing TuJ1, anti-DCC, anti-neuropilin-1, and anti-AN2 antibodies, respectively. We are grateful to Dr. N. Tamamaki for helpful discussions and to Drs. P. Daubersie and A.-S. Lebre for expert technical advice.

*N.S., F.d., and B.L. have contributed equally to this paper.

Correspondence should be addressed to Dr. Jean-Léon Thomas, Institut National de la Santé et de la Recherche Médicale U-495, Biologie des Interactions Neurones/ Glie, Hôpital de la Salpêtrière, 47 Boulevard de l'Hôpital, 75651 Paris cedex 13, France. E-mail: jlthomas@ccr.jussieu.fr.

Copyright (C) 2002 Society for Neuroscience $\quad 0270-6474 / 02 / 225992-13 \$ 15.00 / 0$
}

tenascin-C (Kiernan et al., 1996; Garcion et al., 2001). Growth factors like basic fibroblast growth factor (FGF-2) and platelet derived growth factor (PDGF), secreted along their migratory pathways may also promote the migration of OPCs (Armstrong et al., 1990; Milner et al., 1997). Chemotactic factors of the semaphorin (Messersmith et al., 1995) and netrin (Serafini et al., 1994) families are expressed in the CNS and control the guidance of axonal growth cones (Raper, 2000). Some of them have also been implicated in the migration of neural cells. This is the case for Sema 3A, which has a chemorepulsive effect on neural crest cells (Eickholt et al., 1999) Sema 3A and Sema 3F, which repel cortical interneurons (Marín et al., 2001), and for netrin-1, which guides the migration of precerebellar, cerebellar, and hypothalamic neurons (Bloch-Gallego et al., 1999; Deiner and Sretavan, 1999; Yee et al., 1999; Alcántara et al., 2000). Because neurons and OPCs share common sites of origin in the embryonic neural tube and further develop in close timing (Szele and Cepko, 1998; Perez Villegas et al., 1999; Richardson et al., 2000), we questioned whether semaphorins and netrin molecules could not only act on neurons, but also on glial cells.

Using the mouse optic nerve $(\mathrm{ON})$ as an experimental system, we examined the motility effects of secreted class 3 semaphorins and netrin-1 on OPCs. The ON is a neuron-free extension of the CNS, which is colonized by extrinsic OPCs (Raff et al., 1983; Skoff, 1990). In the rat, OPCs enter the nerve before birth [embryonic day 16 (E16)] and migrate in a chiasmal-to-retinal direction during the first postnatal week (Small et al., 1987). In the present study, we visualize the OPC migration in the embryonic mouse ON. The OPCs enter the chiasm from E14.5 onward and reach the retina at E16.5. To determine whether and how 
secreted semaphorins and netrin- 1 could act as guiding cues on the migration of ON OPCs, we analyzed the expression of class 3 semaphorins, netrin 1, and their specific receptors in OPCs and performed in vitro migration assays on E16.5 ON explants. Altogether, our findings suggest that class 3 semaphorins and netrin-1 act in collaboration during OPC migration.

\section{MATERIALS AND METHODS}

Animals. Transgenic plp-shble-lacZ (Spassky et al., 1998), neuropilin 2-lacZ knock-in (Chen et al., 2000), and OF1 (Iffa-Credo, L'Arbresle, France) mice were used. After anesthesia of the dams, embryos were dissected out and collected in $0.1 \mathrm{M}$ PBS and $0.6 \%$ D-glucose. For the detection of $\beta$-galactosidase ( $\beta$-gal) activity and for in situ hybridization, embryos older than E14.5 were perfused with $4 \%$ paraformaldehyde (PFA) in PBS, pH 7.3.

Optic nerve cultures. ONs from E16-E16.5 plp-shble-lacZ or neuropilin 2-lac $Z$ knock-in embryos were used to establish the migratory test for OPCs. The ON was cut into $150-300 \mu \mathrm{m}$ tissue explants. ON explants were cocultured in rat tail collagen, at a distance $(200-500 \mu \mathrm{m})$ of aggregates of either EBNA-293 cells stably transfected with netrin-1-Cmyc (Keino-Masu et al., 1996) or COS (transformant of CV-1 cells by origin-defective SV-40) cells transfected with Sema 3A-myc (Messersmith et al., 1995), Sema 3F-AP (Chen et al., 1997), Sema 3C-AP (Chen et al., 1997), or Sema $3 E-m y c$ (Chedotal et al., 1998). Control aggregates were EBNA-293 cells or COS cells either untransfected or mocktransfected with a $c m v-G F P$ vector. After each experiment, semaphorin and netrin-1 expression was controlled by Western blot analysis of the culture supernatant using the monoclonal 9E10 anti-myc antibody, or a polyclonal anti-AP antibody (Dako, Glostrup, Denmark). All ON explants, alone or with cell aggregates, were embedded in rat tail collagen, as previously described by Lumsden and Davies (1986). Explants and cell aggregates were cocultured at $37^{\circ} \mathrm{C}$, in Bottenstein-Sato $(\mathrm{B}-\mathrm{S})$ medium supplemented with $1 \%$ L-glutamine, $0.5 \%$ fetal calf serum, and $20 \mathrm{ng} / \mathrm{ml}$ FGF-2 (Boehringer Mannheim, Mannheim, Germany), in a 5\% $\mathrm{CO}_{2}, 95 \%$ humidity incubator. For blocking experiments, antibodies specific of DCC [AF5 monoclonal antibody (mAb); Oncogene Sciences, Uniondale, NY] and neuropilin-1 were added to the culture medium at a final concentration of $1 \mu \mathrm{g} / \mathrm{ml}$, as reported by Keino-Masu et al. (1996) and Bagnard et al. (2001), respectively. After $2 \mathrm{~d}$ in vitro (DIV), the cocultures were fixed in $4 \%$ PFA for immunocytochemistry. To visualize the nuclei, the cultures were then incubated with $5 \mathrm{~mm}$ Hoechst 33258 (Sigma, St. Louis, MO) before being mounted in Fluoromount-G (Clinisciences, Paris, France).

ON cell suspensions were derived from E16.5 plp-shble-lacZ embryos following a procedure slightly modified from Raff et al. (1983). ON nerves were dissected, cut into pieces with microscalpels, and treated for $30 \mathrm{~min}$ at $37^{\circ} \mathrm{C}$ with collagenase (Sigma; $60 \mu \mathrm{g} / \mathrm{ml}$ ) and trypsin (Biological Industries, Israel; $2.5 \mathrm{ng} / \mathrm{ml}$ ) diluted in HBSS without calcium or magnesium (Invitrogen, Gaithersburg, MD). Enzymatic digestion was stopped by addition of an equal volume of $20 \%$ heat-inactivated fetal calf serum (FCS; Invitrogen) in HBSS. After centrif ugation at $1000 \times g$ and resuspension in $\mathrm{B}-\mathrm{S}$ medium containing $10 \% \mathrm{FCS}$, the tissues were triturated with a $20 \mu \mathrm{l}$ siliconized plastic tip, and the cells were recovered by centrifugation at $1000 \times g$. On average, 8000 cells were obtained per E16.5 ON. The resulting cell suspension was seeded at a density of 25,000 cells per well on a monolayer of astrocytes derived from the cerebral cortex and the striatum of E17.5 rats. The astroglial cells were obtained from 2-week-old primary glial cultures, prepared according to Lima et al. (2001), after withdrawal of microglial cells. The ON cells astrocyte coculture was then grown in $500 \mu \mathrm{l}$ of B-S medium supplemented with $1 \%$ L-glutamine, $1 \% \mathrm{FCS}$, and the peptide trophic factors glial growth factor (NeoMarkers, Fremont, CA; $50 \mathrm{ng} / \mathrm{ml}$ ) and NT3 (ReproTech; 1 $\mathrm{ng} / \mathrm{ml})$. After $5 \mathrm{DIV}$, the cultures were fixed in $4 \%$ PFA before immunolabeling.

$\beta$-galactosidase reaction. The $\beta$-galactosidase activity was detected in plp-shble-lacZ and neuropilin-2-lacZ ONs, either with 5-bromo-3-indolyl$\beta$-D-galactoside (Bluo-gal; Invitrogen) or with 5-bromo-4-chloro-3-indolyl$\beta$-D-galactoside (X-gal; United States Biochemical, Cleveland, OH).

Antibodies. To characterize the OPCs, we used mAbs A2B5 (mouse IgM; American Type Culture Collection, Rockville, MD), O4 (mouse IgM; Sommer and Schachner, 1981), as well as the rabbit polyclonal antibody anti-AN2, which recognizes the proteoglycan NG2 (Niehaus et al., 1999; Schneider et al., 2001). A2B5 and O4 mAbs were diluted 1:10 in solution A (5\% bovine serum albumin, $10 \%$ FCS, $1 \%$ gelatin, and
$0.05 \%$ sodium azide in PBS), whereas anti-AN2 was diluted 1:500 in the same solution. Oligodendrocytes were labeled with the $\mathrm{O} 1 \mathrm{mAb}$ (mouse IgM; Sommer and Schachner, 1981) diluted 1:5 in solution A. The astroglial cells were detected with the rabbit polyclonal antibodies antiglial fibrillary acidic protein (GFAP; Dako) and anti-Pax2 (Babco, Richmond, CA) diluted 1:200 and 1:100, respectively, in solution B $(0.2 \%$ gelatin and $0.2 \%$ Triton $\mathrm{X}-100$ in PBS). The neurons were identified with the mouse mAb TuJ1 directed against the $\beta$-tubulin isoform III (IgG2a; Easter et al., 1993; gift of A. Frankfurter, University of Virginia, Charlottesville, VA) diluted 1:2000 in solution B. The rabbit polyclonal anti-neuropilin-1 (Bagnard et al., 2001) was diluted 1:200 in a solution of $1 \%$ FCS and $0.25 \%$ Triton X-100 in PBS. The rabbit polyclonal antiDCC raised against the ectodomain of DCC was diluted 1:500 in PBS (Alcántara et al., 2000). To detect $\beta$-gal-expressing cells, the anti- $\beta$-gal $\mathrm{mAb}$ (mouse IgG1; Chemicon, Temecula, CA) was used diluted 1:200 in $0.1 \%$ Triton X-100 and $1 \%$ FCS in PBS.

Quantitation. After staining with A2B5 mAb and Hoechst, ON explants were examined on a Zeiss Axiophot microscope (Zeiss, Germany). Microphotographs of each individual explant were digitally scanned with a Nikon-CP-9003 camera and transferred to a computer (Imstar). In the homogeneous group of explants selected for quantification, the distance explant-aggregate (D) was $200 \leq \mathrm{D} \leq 500 \mu \mathrm{m}$. In addition, the average surface (S) of the ON explants was $S=663 \pm 31$ $\mu \mathrm{m}^{2}$. The counting was performed by a blind observer, using the morphometrical analysis program (Imstar), as previously described by de Castro et al. (1999). The ON explant was virtually divided into four quadrants with respect to the source of secreted factors (see Fig. $5 A$ ). The number of A2B5- or Hoechst-stained cells was counted in the proximal and distal quadrants, as well as all around the explant. Data were expressed as mean \pm SEM and were statistically analyzed using the Student's $t$ test, ANOVA, and the Pearson's correlation tests (Sigmastat, Jandel Scientific, Germany). Minimal statistical significance for each test used was fixed at $p<0.05$.

In situ hybridization. Brains were processed for in situ hybridization, as reported in Spassky et al. (1998). The antisense riboprobes were labeled with digoxigenin-dUTP (Boehringer Mannheim), using the following cDNAs: DCC and neogenin (Keino-Masu et al., 1996), unc5H1, unc5H2, and unc5H3 (Leonardo et al., 1997), netrin-1 (Serafini et al., 1996), Sema $3 A$ (Messersmith et al., 1995), Sema $3 F$ (a gift of Dr. Harry Drabkin), neuropilin-1 (He and Tessier-Lavigne, 1997), and neuropilin-2 (Chen et al., 1997). The antisense riboprobes were detected with an antidigoxigenin antibody (Boehringer Mannheim).

Bromodeoxyuridine assays. Mouse optic nerves at E16.5 were dissected and dissociated cultures established in 96 well plates, coated with polyL-lysine by adding either control or Sema 3F COS cells culture medium, respectively. Bromodeoxyuridine (BrdU) was added at a concentration of 1:1000 (Garcion et al., 2001), and the cultures were kept at $37^{\circ} \mathrm{C}$ for an average of $43 \mathrm{hr}$. Immunocytochemistry was performed using a BrdU labeling kit (Sigma), and the $\mathrm{BrdU}^{+}$cells were counted on a Leica (Nussloch, Germany) inverted fluorescent microscope.

\section{RESULTS}

\section{Imaging of optic nerve colonization by OPCs}

To provide a chronological picture of oligodendroglial colonization in the $\mathrm{ON}$, we took advantage of the plp-shble-lac $Z$ transgenic mouse. In this line, $\beta$-gal reporter is expressed under the control of regulatory sequences of $p l p$, a gene encoding the major myelin protein. We have previously shown that in the brain of these mice the expression of $\beta$-gal is one of the earliest markers of OPCs (Spassky et al., 1998). ONs were isolated from E13.5-E18.5 plpshble-lacZ embryos and treated with Bluo-gal (Fig. 1). At E13.5, $\beta$-gal-expressing cells were restricted to the suprachiasmatic area in the basoventral diencephalon, and none were detected in the ON. At E14.5, scattered $\beta$-gal ${ }^{+}$cells appeared in the chiasmal part of ON (Fig. 1A). In rostral contact with the ON, a robust expression of $\beta$-gal was also detected within the medial part of the telencephalic preoptic area (Fig. $1 A$ ). At E15.5, the $\beta$-gal ${ }^{+}$cells in the $\mathrm{ON}$ had increased in number and extended toward the retina (Fig. $1 B$ ). At E16.5, a few $\beta$-gal ${ }^{+}$cells had reached the retinal segment (Fig. $1 C$ ). At E17.5, $\beta$-gal ${ }^{+}$cells were distributed all along the nerve. They were, however, more numerous in the 


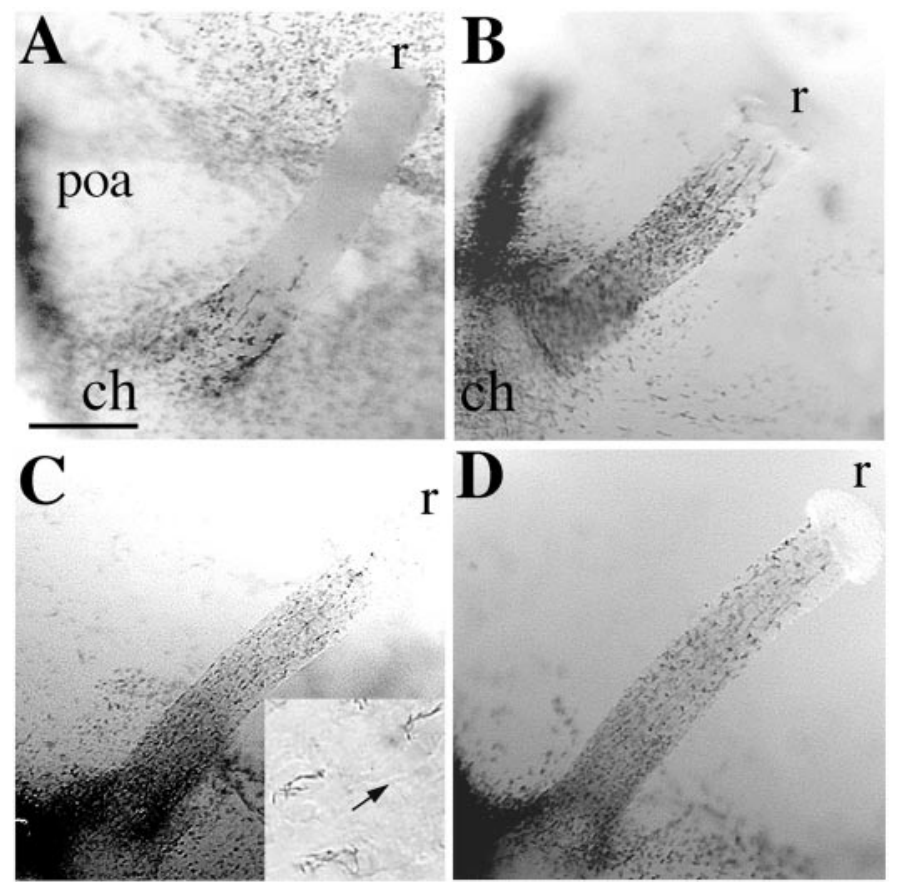

Figure 1. Spatiotemporal pattern of ON colonization by plp-expressing cells. ON isolated from E14.5-E17.5 plp-shble-lacZ embryos were treated in whole mount with Bluo-gal substrate to detect $\beta$-gal enzymatic activity. The $\beta$-gal ${ }^{+}$cells, which are plp expressing cells, colonize the nerve in a chiasmal-to-retinal gradient at E14.5 $(A), \mathrm{E} 15.5(B), \mathrm{E} 16.5(C)$, and E17.5 $(D)$. They show long cytoplasmic extensions parallel to the chiasmal-retinal axis $(C$, inset; the arrow points toward the retina). ch, Chiasm; poa, preoptic area; $r$, retina. Scale bar: $A, B, 110 \mu \mathrm{m} ; C, D, 85 \mu \mathrm{m} ; C$, inset, $25 \mu \mathrm{m}$.

proximal chiasmal half of the $\mathrm{ON}$, and none were observed in the retina (Fig. 1D). Most of these cells showed long cytoplasmic processes orientated parallel to the retinal ganglion cell axons (Fig. 1C, inset), reminiscent of the migrating OPCs with growth cone-like structures observed in the chick (Ono et al., 1997) and rat ON (Kitsukawa et al., 1997). Plp-expressing cells appear therefore to colonize the mouse $\mathrm{ON}$ in a chiasmal-to-retinal gradient between E14.5 and E17.5.

We next investigated the expression of specific markers of early oligodendroglial cells, such as AN2/NG2 and the antigen recognized by A2B5 mAb (Raff et al., 1983; Schneider et al., 2001) in $\mathrm{ON} \beta$-gal ${ }^{+}$cells. ON explants were isolated from plp-shble-lacZ embryos at stage E16.5. After 2 DIV, cultures were treated with Bluo-gal and labeled with either A2B5 mAb or AN2 antibody. Almost all (98\%) Hoechst-positive migrating cells (Fig. 2A-C) were strongly labeled with A2B5 mAb (Fig. $2 B, C, E, F, H, J)$. They were also both $\beta$-gal-positive (Fig. $2 D, F$ ) and AN2/NG2-positive (Fig. $2 G$ ). In addition, none of these cells were stained with anti-GFAP Ab, indicating that they were not astrocytes (Fig. 2I). To unambiguously demonstrate that embryonic ON $\beta$-gal ${ }^{+}$cells differentiate into oligodendrocytes and thus are OPCs, ONs of E16.5 plp-shble-lacZ embryos were dissociated and seeded on a monolayer of rat astrocytes. After 5 DIV, cultures were fixed, treated with Bluo-gal, and immunolabeled with either O4 or O1 mAbs. At $5 \mathrm{DIV}, 34 \pm 2 \%$ of the $\beta$-gal ${ }^{+}$cells were $4^{+}(n=4)$, and $33 \pm 1 \%$ were $\mathrm{O}^{+}(n=4)$. Additional immunolabeling with the neuron-specific antibody $\mathrm{TuJ} 1$ and the astroglial markers anti-GFAP and anti-Pax2 (Mi and Barres, 1999) showed that none of the $\beta$-gal ${ }^{+}$cells were neurons or astrocytes, and were therefore most probably undifferentiated OPCs. Based on their
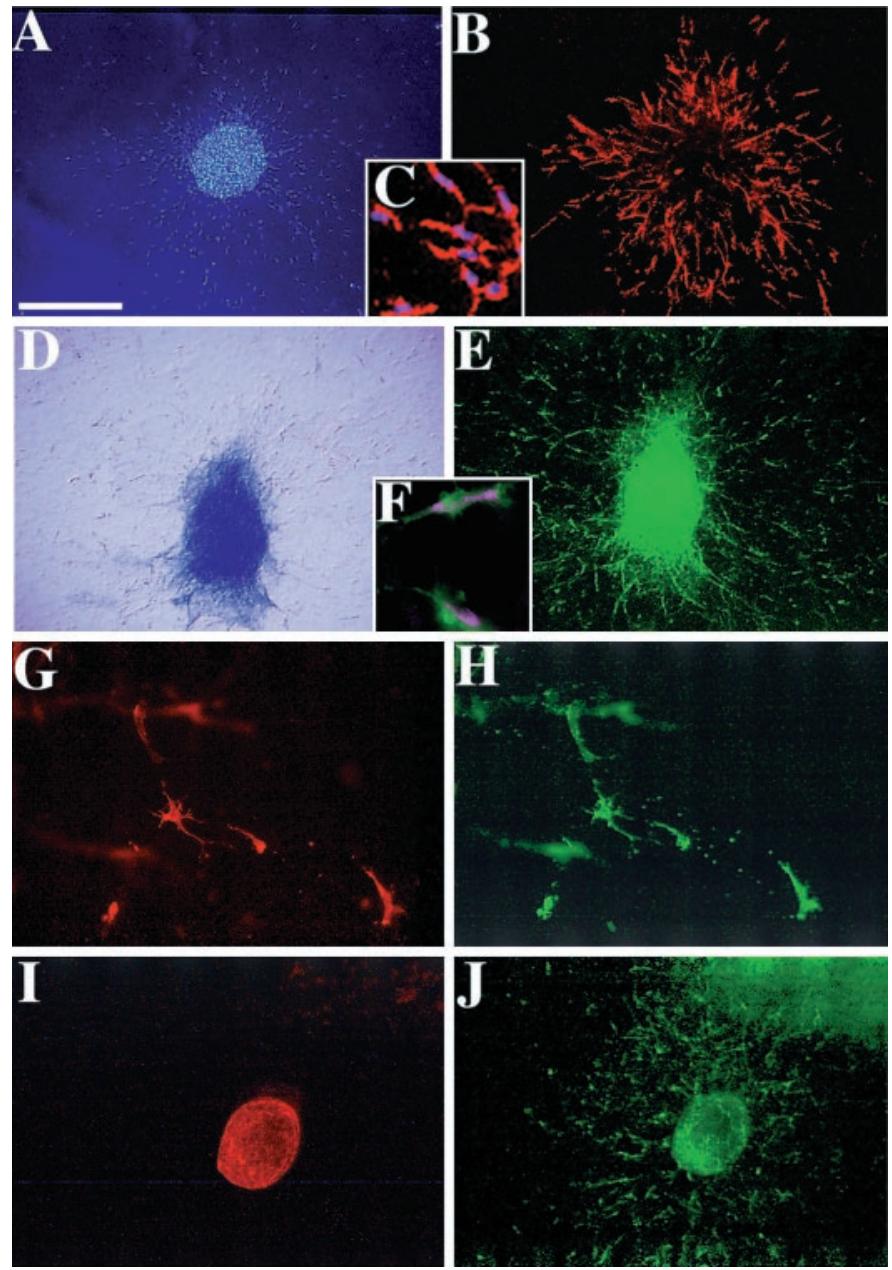

Figure 2. Cells migrating out from E16.5 ON explants belong to the oligodendroglial lineage. ON explants were microdissected from E16.5 plp-shble-lacZ mouse embryos and cultured in a collagen matrix for $48 \mathrm{hr}$. $A-C$, The ON explant was stained with Hoechst reagent $(A$, blue $)$ and immunolabeled with A2B5 mAb $(B, r e d)$. $C$, Higher magnification showing that Hoechst-labeled cells ( purple nuclei) migrating from the explant are strongly $\mathrm{A} 2 \mathrm{~B} 5{ }^{+} . D-F$, The $\mathrm{ON}$ explant was double-labeled with X-gal and $\mathrm{A} 2 \mathrm{~B} 5 \mathrm{mAb}$. Migrating cells are $\mathrm{X}-\mathrm{gal}^{+}(D)$ and $\mathrm{A} 2 \mathrm{~B} 5{ }^{+}(E) . F$ shows an overlay of X-gal (purple) and A2B5 (green) staining. $G, H$, The ON explant was double-labeled with anti-AN2 $(G)$ and A2B5 $(H)$ Abs. All the $\mathrm{A} 2 \mathrm{~B} 5^{+}$cells expressed the AN2/NG2 proteoglycan, specific of oligodendrocyte progenitors. $I, J$, The ON explant was double-labeled with anti-GFAP $(I)$ and A2B5 $(J)$ Abs. None of the A2B5 ${ }^{+}$cells were GFAP ${ }^{+}$. Scale bar: $A, B, 230 \mu \mathrm{m} ; D, E, I, J, 150 \mu \mathrm{m} ; C, 60 \mu \mathrm{m} ; F-H, 25 \mu \mathrm{m}$.

expression of $\mathrm{AN} 2 / \mathrm{NG} 2$ proteoglycan and reactivity to $\mathrm{A} 2 \mathrm{~B} 5$ $\mathrm{mAb}$, as well as on their elongated morphology and their ability to differentiate into $\mathrm{O}^{+}$oligodendrocytes, the $\beta$-gal ${ }^{+}$cells invading the plp-shble-lacZ ON from E14.5 onward fulfill the established criteria for OPCs.

\section{Sema 3F modulates the proliferation of OPCs}

Using ON explants isolated at E16.5 as a source of OPCs, we questioned whether the secreted factors netrin-1, Sema 3A, Sema $3 \mathrm{C}$, Sema 3E, and Sema 3F acted on OPC proliferation. After 2 DIV, the distribution of OPCs was revealed by staining with A2B5 mAb and Hoechst, and the number of cells that exited from explants was quantitated. The number of OPCs migrating from ON explants in control cultures $(414 \pm 37$ cells per explant; $n=$ $30)$ and in the presence of Sema $3 \mathrm{~A}(416 \pm 43$ cells per explant; 
A

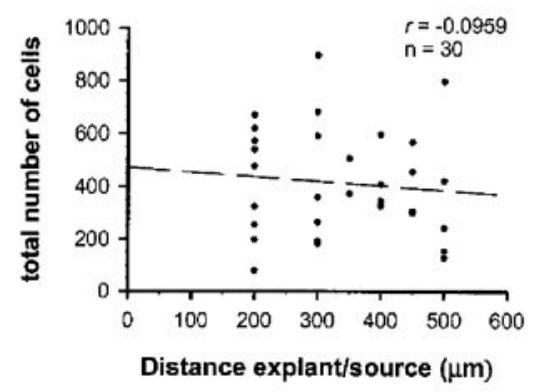

C

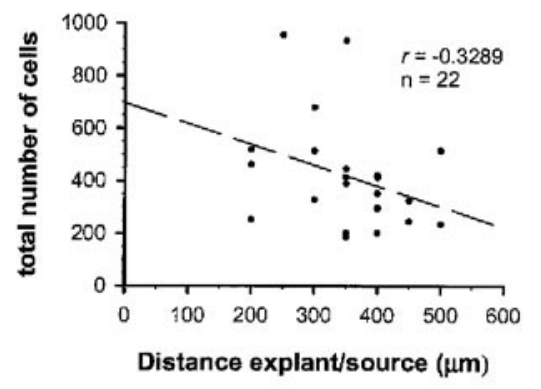

E

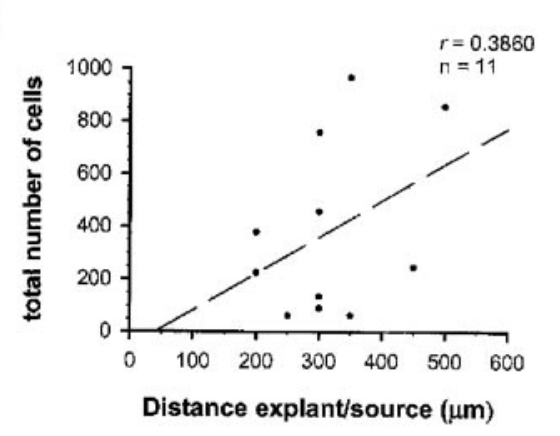

B

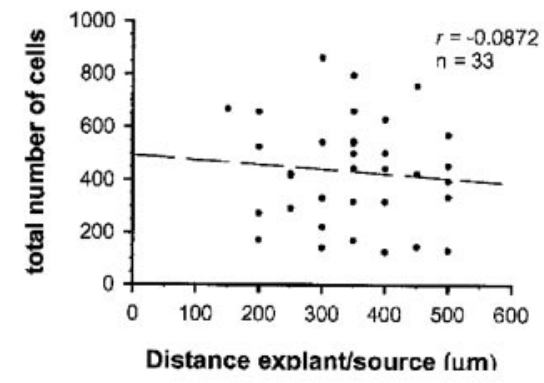

$\mathrm{D}$

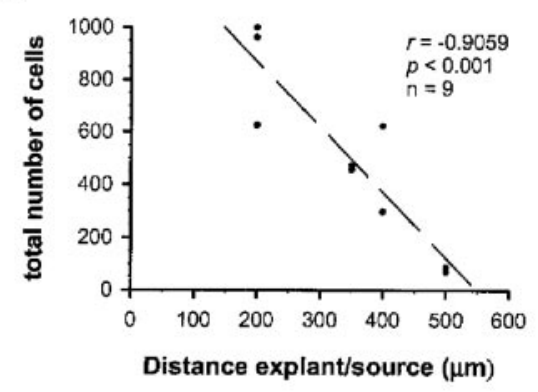

$\mathrm{F}$

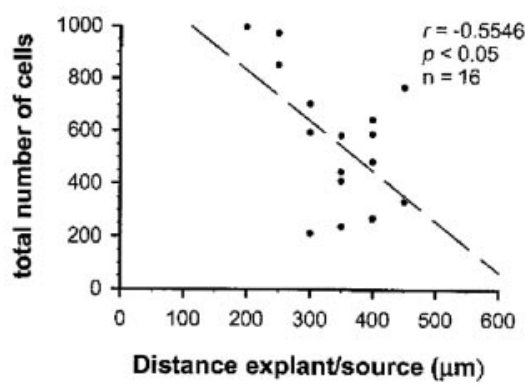

Figure 3. OPC migration as a function of the distance from semaphorins and netrin-1 secreting cells. ON explants were confronted to control cells $(A)$, netrin-1 $(B)$, Sema 3A $(C)$, Sema 3C $(D)$, Sema 3E $(E)$, or Sema $3 \mathrm{~F}(F)$ secreting cells. To examine whether the amount of cell migration was dependent on the concentration of secreted factor available, a correlation ( $r$, Pearson's correlation coefficient; $p$, statistical significance of the test) was established between the number of cells migrating out from ON explants and the distance between the $\mathrm{ON}$ explant and the source of secreted factor. The correlation is significant only for Sema $3 \mathrm{C}$ and Sema $3 \mathrm{~F}(p<0.05)$, which suggests that both factors might have a trophic effect on OPCs. $n=22)$, Sema 3C (510 \pm 111 cells per explant; $n=9)$, Sema 3E (385 \pm 100 cells per explant; $n=11)$, or netrin-1 (424 \pm 35 cells per explant; $n=33$ ) was similar ( $p>0.1$; Student's $t$ test). In contrast, a significantly higher number of migrating cells was observed in cocultures with Sema 3F-secreting cells $(553 \pm 61$ cells per explant; $n=16 ; p<0.05)$. To determine whether the amount of cell migration was influenced by the concentration of secreted factors, we evaluated the number of migrating cells in function of the distance between $\mathrm{ON}$ explant and factor-secreting cells (Fig. 3). No significant correlation between the number of migrating cells in function of the distance between $\mathrm{ON}$ explant and factor-secreting cells was observed for ON explants cocultured with netrin-1, Sema $3 \mathrm{~A}$, and Sema $3 \mathrm{E}$, suggesting that these factors did not affect the proliferation of OPCs (Fig. $3 A-C, E$ ). In contrast, a significant increase in the number of cells was observed around ON explants near the source of Sema 3F $(r=$ -0.5546 ; Pearson's correlation test, $p<0.05$ ) (Fig. 3F). The mitogenic effect of Sema 3F was further evidenced by the evaluation of BrdU incorporation in $\mathrm{ON}$ dissociated cell cultures. In the presence of Sema $3 \mathrm{~F}$, there was a $43 \%$ increase in the number of $\mathrm{BrdU}^{+}$cells $\left(15.6 \pm 1.7 \mathrm{BrdU}^{+}\right.$cells of $103 \pm 7.4 \mathrm{~A} 2 \mathrm{~B} 5^{+}$cells; $n=17)$ compared with control $\left(9.5 \pm 1.2 \mathrm{BrdU}^{+}\right.$cells of $89 \pm 4.2$ $\mathrm{A} 2 \mathrm{~B} 5{ }^{+}$cells; $\left.n=7\right)$. In addition, a small increase in the number of migrating cells was also observed in the presence of Sema $3 \mathrm{C}$ (Fig. 3D). This could be attributable to a number of possible actions of this factor. However, because no significant chemotropic effect was detected for Sema 3C (see below), further investigations about this factor were not pursued in this paper. It is worth noting that, under all the culture conditions used, only very few picnotic nuclei were observed around the explants (data not shown), suggesting that neither the presence nor the absence of secreted factors induced cell death in OPCs.

\section{Sema 3F, Sema 3A, and netrin-1 guide OPC migration}

We next examined a possible directional effect of class 3 semaphorins and netrin-1 on OPC migration. Cells labeled with A2B5 $\mathrm{mAb}$ showed three main types of migration around $\mathrm{ON}$ explants. In control experiments, all four quadrants of each explant were homogeneously colonized by the A2B5 ${ }^{+}$OPCs (Fig. 4A,B). The number of migrating cells was similar in the proximal (PQ) and distal (DQ) quadrants surrounding the explants $(P Q=104 \pm 10$; $\mathrm{DQ}=96 \pm 10)$ (Fig. 5). The same radial pattern of migration was observed around the $\mathrm{ON}$ explants confronted to Sema $3 \mathrm{C}$ - and Sema 3E-secreting cells (Fig. 4C,D). No differences were observed in the number of migrating cells in the proximal and distal quadrant of Sema $3 \mathrm{C}(\mathrm{PQ}=108 \pm 28 ; \mathrm{DQ}=111 \pm 26)$ and Sema $3 \mathrm{E}(\mathrm{PQ}=145 \pm 32 ; \mathrm{DQ}=135 \pm 30)$ cultures. In spite of a quite large variance in the means of results, this finding suggests that neither Sema 3C nor Sema 3E acts on the guidance of OPCs. In contrast, in the presence of Sema 3A (Fig. 4G), the migrating cells 

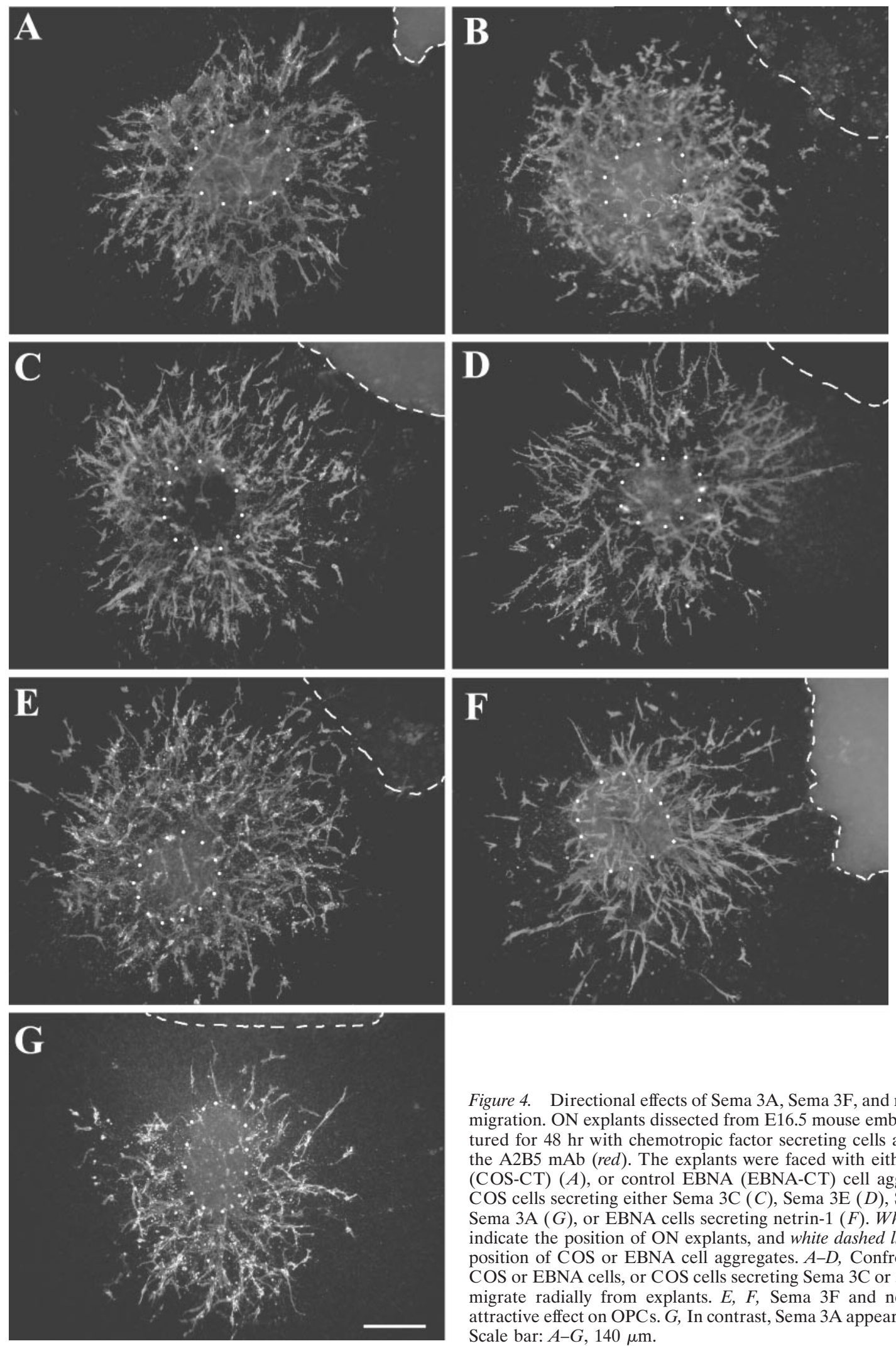

Figure 4. Directional effects of Sema 3A, Sema 3F, and netrin-1 on OPC migration. ON explants dissected from E16.5 mouse embryos were cocultured for $48 \mathrm{hr}$ with chemotropic factor secreting cells and stained with the A2B5 mAb (red). The explants were faced with either control COS $(\mathrm{COS}-\mathrm{CT})(A)$, or control EBNA (EBNA-CT) cell aggregates $(B)$, or COS cells secreting either Sema $3 \mathrm{C}(C)$, Sema $3 \mathrm{E}(D)$, Sema $3 \mathrm{~F}(E)$, or Sema 3A $(G)$, or EBNA cells secreting netrin-1 $(F)$. White dotted circles indicate the position of ON explants, and white dashed lines indicate the position of COS or EBNA cell aggregates. $A-D$, Confronted to control COS or EBNA cells, or COS cells secreting Sema $3 \mathrm{C}$ or $3 \mathrm{E}, \mathrm{A} 2 \mathrm{~B} 5^{+}$cells migrate radially from explants. $E, F$, Sema $3 F$ and netrin- 1 show an attractive effect on OPCs. $G$, In contrast, Sema $3 \mathrm{~A}$ appears to repel OPCs. Scale bar: $A-G, 140 \mu \mathrm{m}$.

were mostly distributed in the quadrant of ON explants distal of the source compared with the proximal quadrant $(\mathrm{PQ}=90 \pm 9$; $\mathrm{DQ}=133 \pm 15 ; p<0.05$ ) (Fig. 5). The opposite effect was observed in the presence of Sema $3 \mathrm{~F}$ or netrin-1 (Fig. $4 E, F$ ). The migrating OPCs were attracted toward the source of Sema $3 \mathrm{~F}$ $(\mathrm{PQ}=181 \pm 19 ; \mathrm{DQ}=121 \pm 21 ; p<0.005)$, and netrin-1 $(\mathrm{PQ}=$ $138 \pm 12 ; \mathrm{DQ}=108 \pm 11 ; p<0.05)$ (Fig. 5).

To assess the apparent attractive effect of Sema $3 \mathrm{~F}$ and 
A

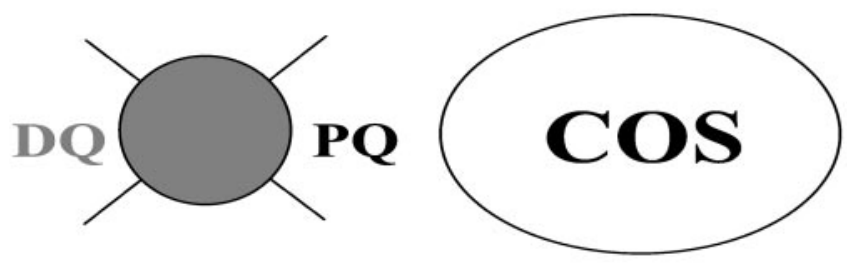

B

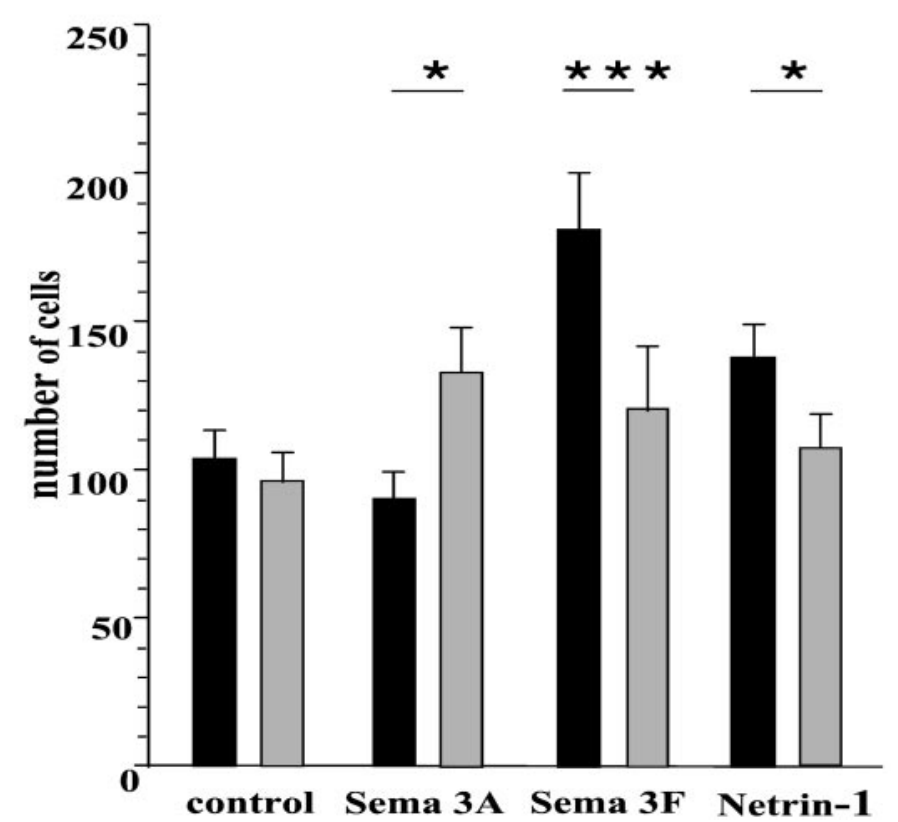

Figure 5. Quantitation of the directional effects of Sema 3A, Sema 3F, and netrin-1 on OPC migration. E16.5 mouse ON explants were cultured as illustrated in Figure 4. Only explants distant 200-500 $\mu \mathrm{m}$ from COS-EBNA cell aggregates were analyzed. $A$, Each explant was virtually divided into four quadrants with respect to the source of secreting factors. $P Q$, Proximal quadrant; $D Q$, distal quadrant. $B$, The number of Hoechst ${ }^{+}$cells migrating from ON explants was counted in both the proximal quadrant (black columns) and the distal quadrant ( gray columns). * $p<0.05$; *** $p<0.005$ (Student' $\mathrm{s} t$ test between PQ and DQ in each case).

netrin-1, we performed "tandem coculture experiments" like those used to demonstrate directionality of axon guidance (Lumsden and Davies, 1983; Ebens et al., 1996) and pontine cell migration (Yee et al., 1999). In these experiments $(n=5)$, two ON explants were cocultured at different distances from an aggregate of Sema 3F (Fig. 6A-C) or netrin-1-secreting cells. In the presence of either Sema $3 F$ or netrin-1, the number of migrating cells in the proximal quadrant of the far ON explant was double than the number of migrating cells in the distal quadrant of the near ON explant (Fig. 6D). Therefore, the concentration of factor, which is higher near the secreting source than further from it, is probably not the major determinant accounting for the directional effect of Sema 3F or netrin-1. The guidance of OPCs by Sema $3 \mathrm{~F}$ and netrin-1 might more likely reflect a chemotactic response to a gradient between the source of factor and $\mathrm{ON}$ explants. Similar "tandem coculture experiments" between ON explants and Sema 3A-secreting cells confirmed the apparent repulsive effect of Sema 3A on OPCs in the mouse ON (Fig. 6D). Altogether, these results provide evidence that OPCs entering the mouse $\mathrm{ON}$ are attracted by netrin- 1 and Sema $3 \mathrm{~F}$ and repelled by Sema $3 \mathrm{~A}$.

\section{OPCs express both Sema 3 and netrin-1 receptors}

Based on the motility effects observed in vitro for Sema 3A, Sema $3 \mathrm{~F}$, and netrin-1, we examined whether OPCs expressed their corresponding receptors. Using the culture system described above, we analyzed the oligodendroglial expression of DCC, a netrin-1 receptor (Keino-Masu et al., 1996), neuropilin-1, the high-affinity receptor of Sema 3A (Kitsukawa et al., 1997; Kolodkin et al., 1997), and neuropilin-2, an essential component of the Sema 3F receptor (Chen et al., 1997, 2000; Giger et al., 2000). E16.5 ON explants were immunolabeled at 2 DIV with A2B5 $\mathrm{mAb}$ (Fig. 7A,C) and either anti-DCC (Fig. 7B), or antineuropilin-1 Ab (Fig. 7D). Almost all the migrating A2B5 ${ }^{+}$cells $(>95 \%)$ also expressed both DCC and neuropilin-1. Expression of neuropilin-2 was investigated in neuropilin-2 -lacZ knock-in heterozygous mice in which lac $Z$ is inserted into the neuropilin-2 locus (Chen et al., 2000). ON explants from E16.5 heterozygous neuropilin-2-lac $Z$ mice were cultured for $48 \mathrm{hr}$ and immunolabeled with both anti- $\beta$-gal and A2B5 antibodies. We observed that $\mathrm{A} 2 \mathrm{~B} 5^{+}$cells expressed $\beta$-gal ${ }^{+}$, i.e., were neuropilin- $2^{+}$(Fig. 7E,F).

To determine whether the receptors for class 3 semaphorins and for netrin- 1 were expressed in vivo in the $\mathrm{ON}$ at the time of OPC colonization, cryosections of E18.5 ON were hybridized with the antisense riboprobes of semaphorin receptors neuropilin-1 and neuropilin-2, and of the different netrin-1 receptors: DCC, neogenin, unc5H1, unc5H2, and unc5H3. No signal for neogenin, unc $5 \mathrm{H} 2$, or unc $5 \mathrm{H} 3$ transcripts were detected in the $\mathrm{ON}$. In contrast, a specific expression of neuropilin-1, neuropilin-2, DCC, and unc5H1was observed in ON cells (Fig. 8). The neuropilin- $1^{+}$cells were scattered within the nerve as well as along the perineural mesenchyme (Fig. 8A). On plp-shble-lacZ ON cryosections, double-labeling with the neuropilin-1 riboprobe and anti- $\beta$-gal $\mathrm{Ab}$ showed that the vast majority of neuropilin- $1^{+}$ cells were also $\beta$-gal ${ }^{+}$(Fig. $8 A$, inset), which indicates that they are OPCs. Neuropilin-2 transcripts were also detected in the developing $\mathrm{ON}$, and the distribution of neuropilin- $2^{+}$cells was similar to that of neuropilin- $1^{+}$cells (Fig. $8 B$ ). Double-labeling experiments with the neuropilin- 2 riboprobe and anti- $\beta$-gal Ab on E18.5 plp-shble-lacZ ON confirmed that neuropilin-2 transcripts were expressed by $\beta$-gal ${ }^{+}$cells (Fig. $8 B$, inset). The $D C C$ transcripts were also expressed in the ON (Fig. $8 C$ ), by $\beta$-gal ${ }^{+}$cells (Fig. $8 C$, inset). The $D C C^{+}$cells were more numerous in the temporal side of the ON chiasmal segment (Fig. 8D), as well as in the retinal end, close to the papilla. At E18.5, the average number of DCC-expressing cells per optic nerve was $2346 \pm 367(n=2)$. Cells positive for unc 5 H1were also detected in the E18.5 ON (Fig. $8 E)$. However, they were less numerous $(1153+196 ; n=2)$, and the intensity of the signal was weaker, as suggested by the fact that, in comparison with DCC mRNAs, the detection of unc5H1 transcripts required a longer period of revelation in nitrobluetetrazolium-chloride-5-bromo-4-chlor-indolyl-phosphate substrate (4 and $6 \mathrm{hr}$, respectively). To determine whether the pattern of expression of these two receptors of netrin- 1 was modified during ON development, we compared DCC and unc5H1 expression at postnatal day 5 (P5). At P5, the level of expression of unc5H1 had 

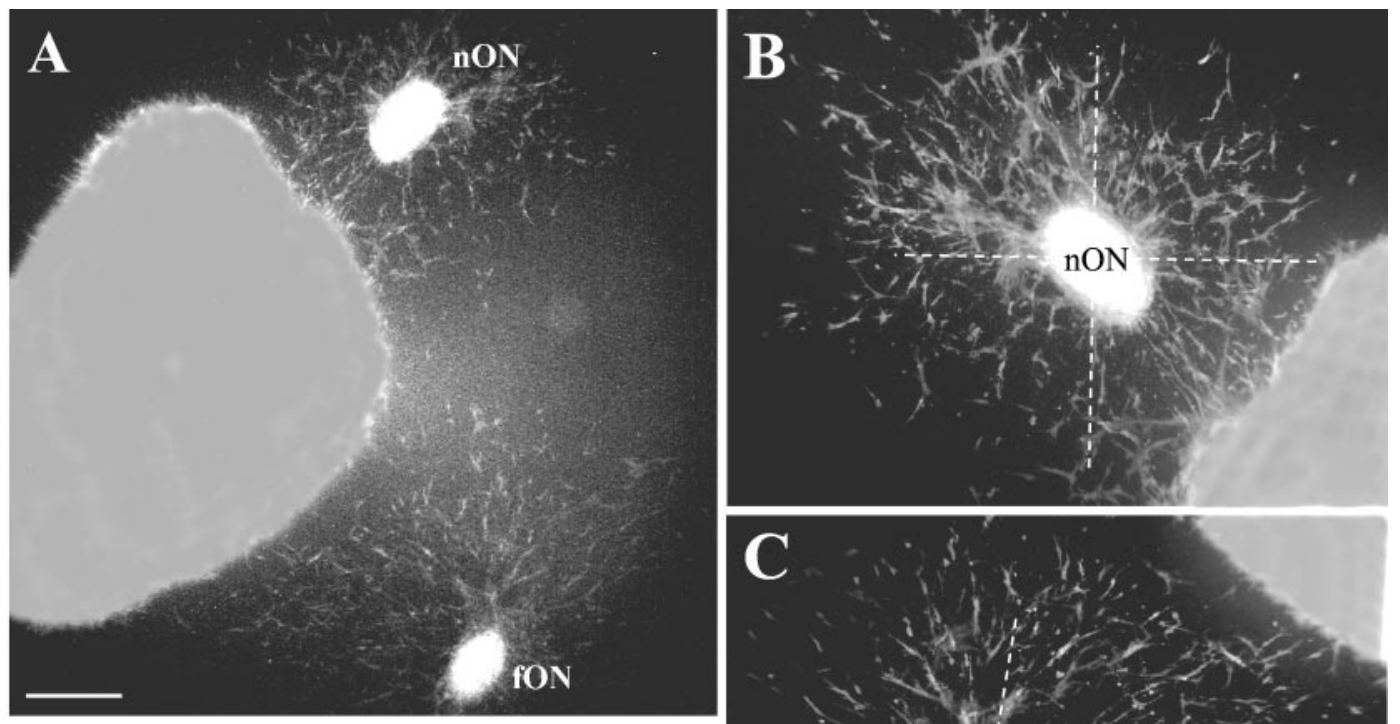

D
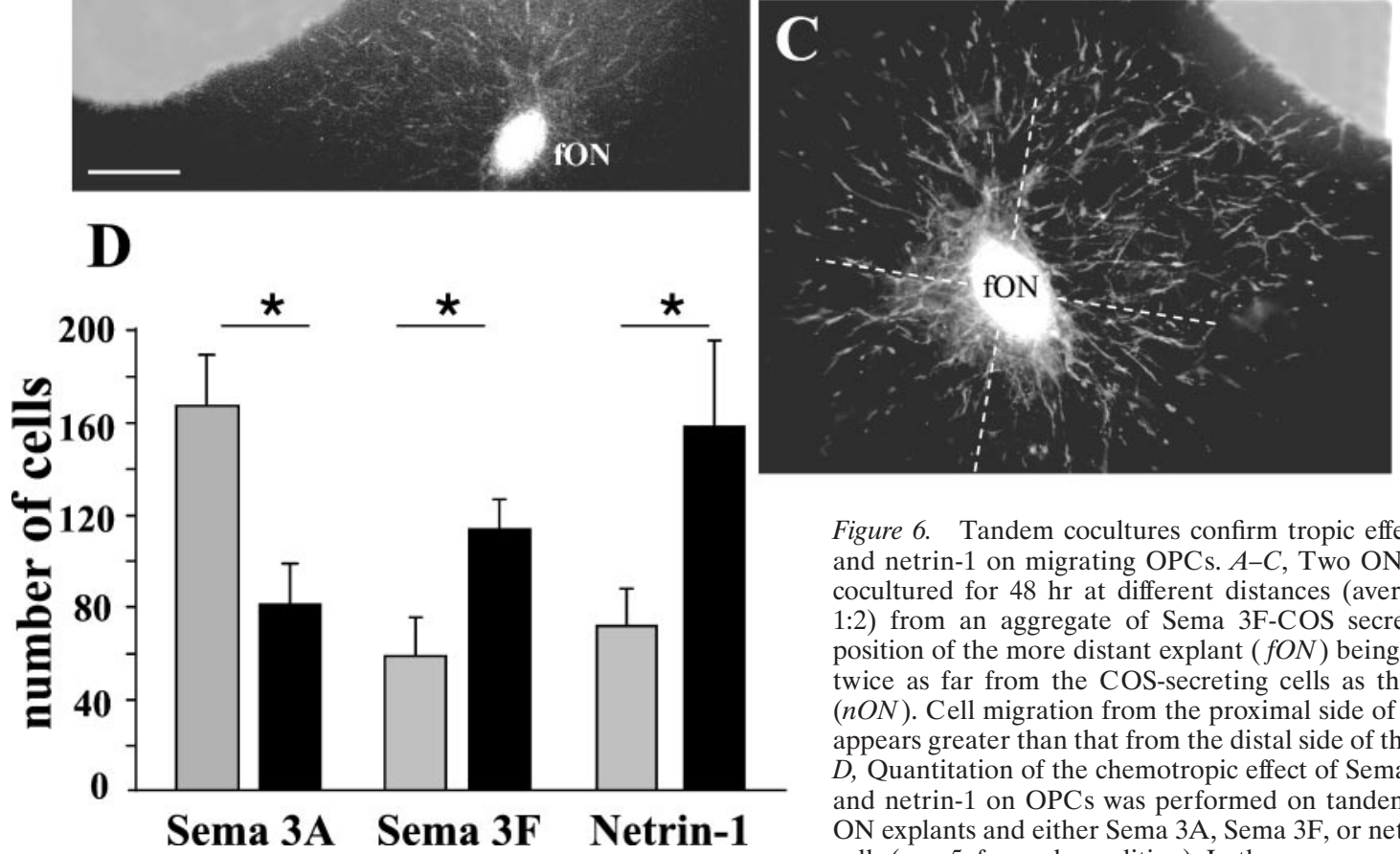

Figure 6. Tandem cocultures confirm tropic effect of Sema 3F and netrin- 1 on migrating OPCs. $A-C$, Two ON explants were cocultured for $48 \mathrm{hr}$ at different distances (average difference, 1:2) from an aggregate of Sema 3F-COS secreting cells, the position of the more distant explant $(f O N)$ being approximately twice as far from the COS-secreting cells as the near explant $(n O N)$. Cell migration from the proximal side of the far explant appears greater than that from the distal side of the near explant. $D$, Quantitation of the chemotropic effect of Sema 3A, Sema 3F, and netrin-1 on OPCs was performed on tandem cocultures of ON explants and either Sema 3A, Sema 3F, or netrin-1-secreting cells $(n=5$, for each condition). In the presence of Sema 3A, the number of cells counted in the proximal quadrant of the far explant (black columns) was significantly lower than the number of cells localized in the dista quadrant of the near explant (gray columns) (average ratio, 2.0; ${ }^{*} p<0.05$ ). In contrast with Sema $3 \mathrm{~F}$ or netrin-1, the number of cells counted in the proximal quadrant of the far explant (black columns) was significantly higher than the number of cells localized in the distal quadrant of the near explant ( gray columns), both in the presence of Sema 3F (average ratio, 1.5; $p<0.05$ ) and in the presence of netrin-1 (average ratio, 2.2; $p<0.05$ ). These data are indicative of a chemotactic response of OPCs to a gradient of Sema 3A, Sema 3F, and netrin-1 between the source of factor and ON explants. Scale bar: $A, 400 \mu \mathrm{m} ; B, C, 290 \mu \mathrm{m}$.

increased, and unc5H1 transcripts were detected in $\beta$-gal ${ }^{+}$cells of the ON (Fig. $8 F$, inset), especially in the retinal end, close to the papilla, whereas the $D C C$-expressing cells were randomly distributed in ON cells (data not shown). The average number of labeled cells was $5380 \pm 905(n=2)$ and $4950 \pm 85(n=2)$ for DCC and unc $5 \mathrm{H1}$, respectively. Altogether, these results indicate that OPCs migrating into the $\mathrm{ON}$ express receptors for class 3 semaphorins and netrin-1.

\section{Inhibition of Class 3 semaphorins and netrin-1 receptors changes the migratory properties of OPCs}

To determine whether the guidance effect of Sema 3A, Sema 3F, and netrin- 1 was mediated by the interaction of these ligands with their specific receptors, we performed experiments in which the biological activity of the receptors neuropilin-1, neuropilin-2, or DCC were abolished. Two blocking antibodies raised against neuropilin-1 and DCC were added to ON explants cocultured with Sema 3A and netrin-1, respectively. Although no significant effect on the number of migrating cells was observed in the presence of anti-neuropilin-1 $(421 \pm 19 ; n=11)$ or anti-DCC (360 $\pm 36 ; n=13$ ) Abs, the directional effects of Sema 3A and netrin-1 were abolished (Fig. 9). The migratory cells were equally distributed in the proximal and distal quadrants of ON explants cultured with Sema 3A + anti-neuropilin-1 (PQ = $106 \pm 19$; $\mathrm{DQ}=104 \pm 19)$, and with netrin-1 + anti-DCC $(\mathrm{PQ}=81 \pm 17$; $\mathrm{DQ}=89 \pm 18)$. Because blocking antibodies against neuropilin-2 were not available, we used the $\mathrm{ON}$ of neuropilin-2-lacZ knock-in mice, which bears a loss of function mutation of neuropilin-2 receptor, as a source of tissue. In the presence of Sema $3 F$, the amount of cell migration from $\mathrm{ON}$ explants derived from homozygous neuropilin- $2^{-1-}$ - lac $Z$ embryos $(n=7)$ and in control ON explants derived from heterozygous neuropilin- $2^{+/-}-$lacZ embryos $(n=12)$ was similar. In contrast, the directional migration of OPCs observed in control cultures $(\mathrm{PQ} / \mathrm{DQ}=1.95 ; p<$ $0.005)$ was no longer observed in cultures derived from homozygous neuropilin- $2^{-/-}$- lacZ $(\mathrm{PQ} / \mathrm{DQ}=1.03)$. These results therefore strongly suggest that the effects of Sema $3 \mathrm{~A}$, Sema $3 \mathrm{~F}$, and 

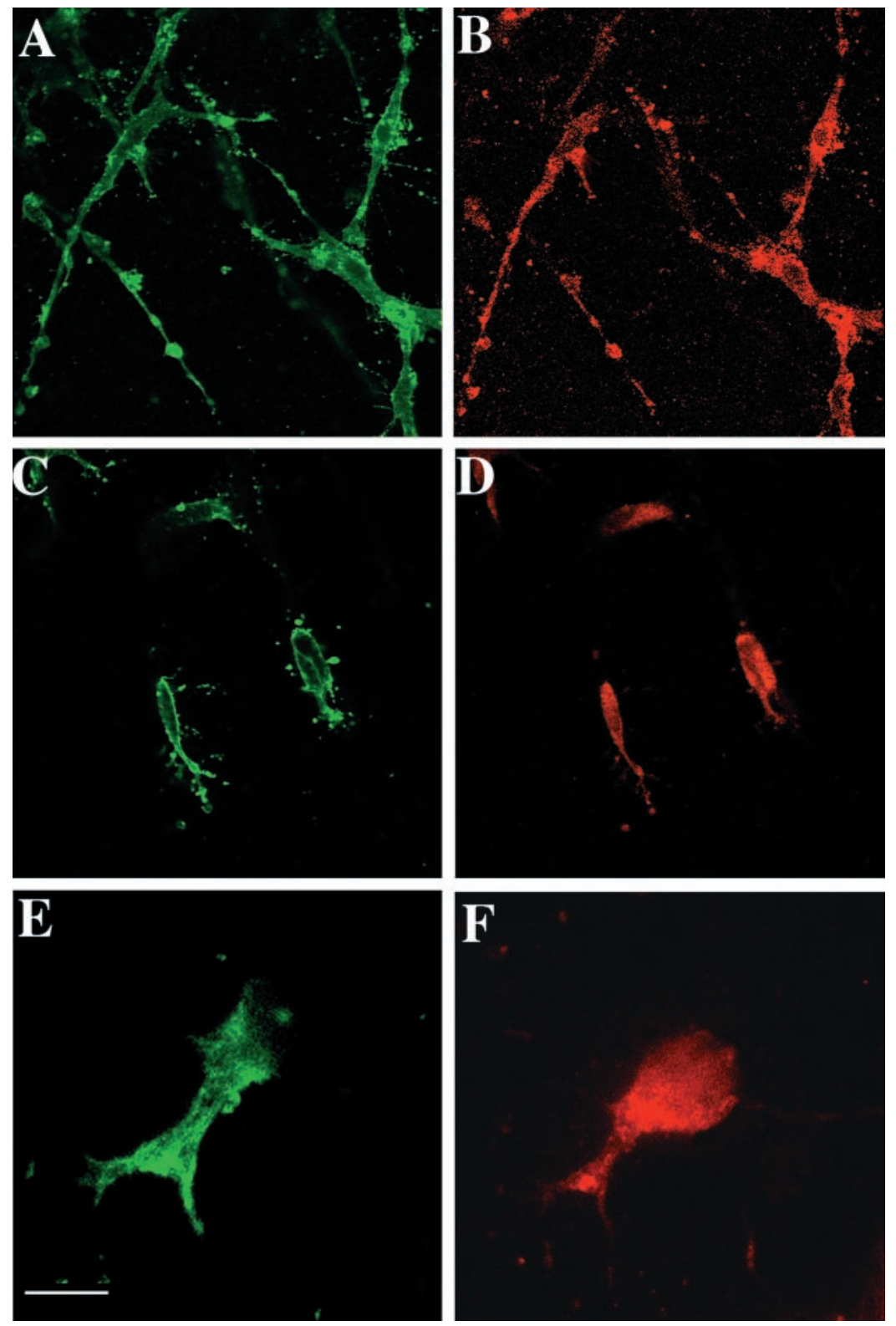

Figure 7. Semaphorin 3 and netrin-1 receptors are expressed by OPCs in vitro. $A-D$, ON explants from E16.5 OF1 mice were cultured for $48 \mathrm{hr}$ and then immunolabeled with $\mathrm{A} 2 \mathrm{~B} 5 \mathrm{mAb}(A, C)$ and either anti-DCC $(B)$ or antineuropilin-1 $(D)$ antibodies. Almost all the migrating A2B5 ${ }^{+}$ cells $(A, C)$ express DCC $(B)$ and neuropilin-1 $(D) . E, F$, ON explants from E16.5 neuropilin- $2^{+/-}$-lacZ heterozygous mice were cultured for $48 \mathrm{hr}$ and then immunolabeled with A2B5 $(E)$ and anti- $\beta$-gal $(F)$ antibodies. Scale bar: $A, B, 40 \mu \mathrm{m} ; C$, $D, 25 \mu \mathrm{m} ; E, F, 10 \mu \mathrm{m}$. netrin-1 on OPC migration require an interaction with neuropilin-1, neuropilin-2, and DCC, respectively.

\section{Expression of Sema 3A, Sema 3F, and netrin-1 in the ON territory}

To determine whether, in vivo, the site of expression of Sema $3 A$, Sema $3 F$, and netrin- 1 was compatible with the chemotropic effect above described, cryosections of embryonic brain isolated at E16.5 and E18.5 were hybridized with Sema 3A, Sema $3 F$, and netrin-1 antisense riboprobes. Cells expressing Sema $3 A$ transcripts were only detected in the perineural mesenchyme, which surrounds the nerve (Fig. 10 $A, B$ ) and extends toward the retina as well as under the ventral diencephalon. Netrin-1-expressing cells were localized in the anterior part of the chiasm and in the nerve. At E18.5, netrin- $1^{+}$cells were concentrated in the optic papilla (Fig. 10C) and in the temporal quadrant (Fig. 10D) of the ON. This distribution pattern of netrin- $1^{+}$cells is reminiscent of the one described for $D C C$. Immunolabeling of $\mathrm{ON}$ cryosections was performed with either anti-GFAP or anti-NG2 antibodies after in situ hybridization with the netrin-1 antisense riboprobe. The majority of netrin- $1^{+}$cells in the temporal quadrant and the papilla of the $\mathrm{ON}$ were $\mathrm{GFAP}^{+}$astrocytes (Fig. 10E, inset). The $\mathrm{NG} 2{ }^{+}$cells migrating in the chiasmal segment were netrin-1negative (Fig. 10F). However, at the retinal end, a few $\mathrm{NG}_{2}{ }^{+}$ cells were also netrin- $1^{+}$(Fig. $10 F$, inset), suggesting that more mature oligodendrocytes express netrin-1, as previously shown (Manitt et al., 2001). The transcripts of Sema $3 F$ were not detected along the ON, but were highly expressed all through the retina (Fig. 10G), in the photoreceptor and the retinal ganglion cell $(G$, inset) layers.

\section{DISCUSSION}

\section{Early OPCs colonize the ON}

In the present study, we visualize migrating OPCs by using plp-shble-lac $Z$ transgenic mice. We show that the mouse $\mathrm{ON}$ is colonized in a chiasmal-to-retinal gradient from E14.5 onward. The OPCs migrating into the embryonic mouse $\mathrm{ON}$ are $\mathrm{NG}_{2}^{+}$/ 

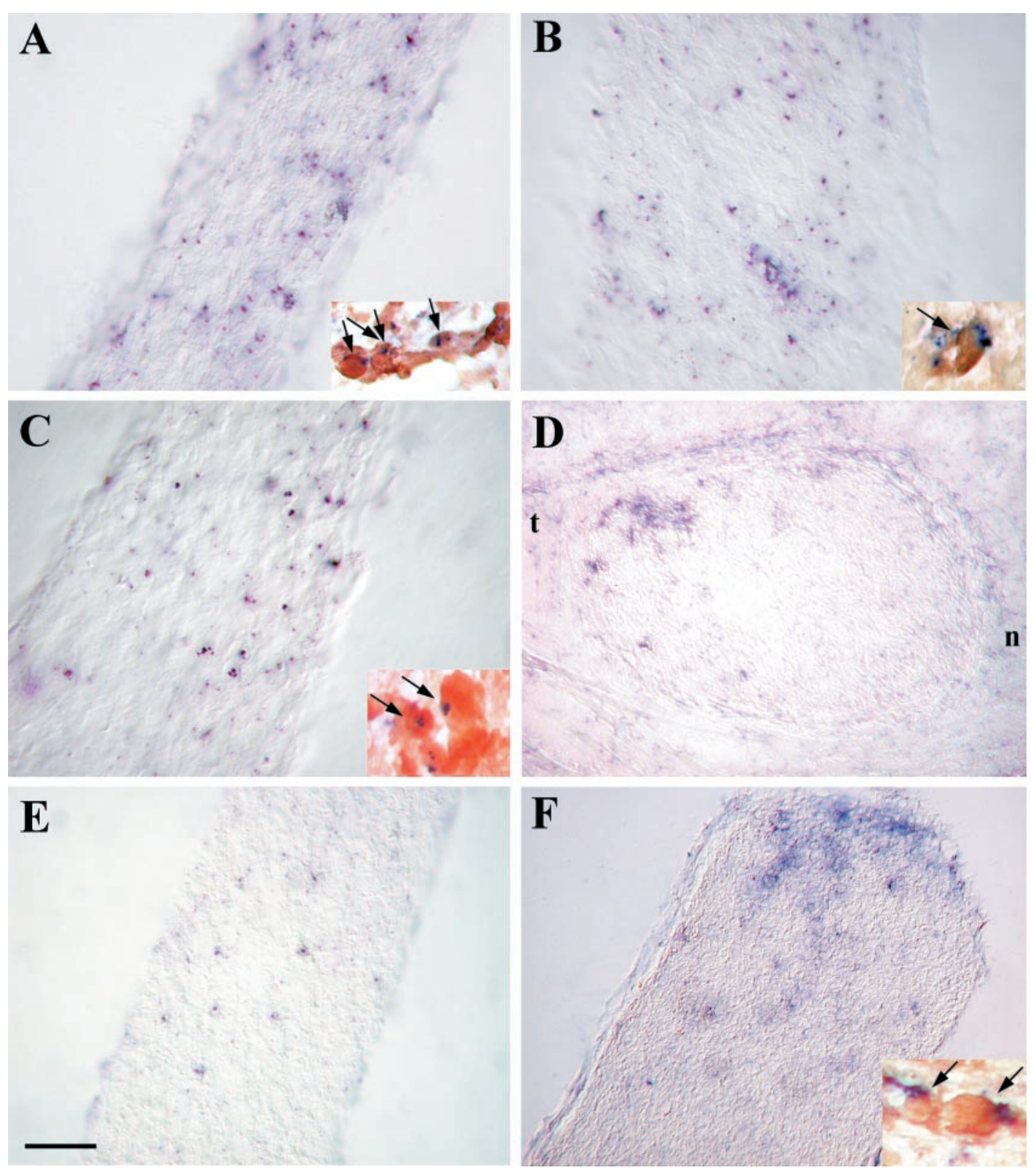

Figure 8. Semaphorin 3 and netrin-1 receptors are expressed by ON OPCs, in vivo. ONs were isolated from plp-shble-lacZ mice at E18.5 ( $A-E$ ) and P5 $(F)$. Longitudinal $(A-C, E, F)$ and coronal $(D)$ cryosections were hybridized with digoxigenin-labeled neuropilin-1 $(A)$, neuropilin-2 $(B), D C C(C, D)$, and unc5H1 (E, F) antisense riboprobes (in blue). To detect OPCs, cryosections were additionally labeled with anti- $\beta$ gal Ab (in brown) (insets in $A-C$, $F$, respectively). $A-D$, At E18.5, the ON express neuropilin-1 $(A)$, neuropilin-2 $(B)$, and $D C C(C, D)$. As shown on insets in $A-C$, the labeled cells are $\beta$-gal ${ }^{+}$OPCs (in brown and blue; arrows). Note that the $D C C$ transcripts are expressed within the temporal quadrant of the nerve $(t$ in $D) . n$, Nasal; $t$, temporal. E, F, At E18.5, the signal for unc5H1 is weak and detectable in few cells in the ON. In contrast, at P5, numerous cells are expressing unc5H1 $(F)$, and these cells are $\beta$-gal ${ }^{+}$OPCs $(F$, inset $)$. Note the concentration of $u n c 5 H 1^{+}$cells in the retinal end of the ON. Scale bar: $D, F, 50 \mu \mathrm{m} ; E, 35 \mu \mathrm{m}$; $A-C, 30 \mu \mathrm{m} ; A, B$, insets, $20 \mu \mathrm{m} ; C$, inset, $15 \mu \mathrm{m} ; F$, inset, $10 \mu \mathrm{m}$.

$\mathrm{A} 2 \mathrm{~B} 5{ }^{+}$. This is in agreement with the report by Fanarraga et al. (1995), according to which OPCs are initially A2B5 ${ }^{+}$then downregulate $\mathrm{A} 2 \mathrm{~B} 5$ expression for a few days before starting to express O4-reactive antigen. In the rat ON, Small et al. (1987) have shown that OPCs enter the chiasm from E16 and migrate toward the retinal end of the nerve. Considering that the developmental process in the rat is delayed by $\sim 48 \mathrm{hr}$ in comparison with the mouse, the chronology of ON colonization by OPCs appears identical in these two species.

In the mouse $\mathrm{ON}$, the first PDGFR $\alpha$-expressing OPCs are detected in the chiasmal segment only at E19-P0 (our unpub- lished results; Wallace and Raff, 1999). The earlier invasion of the ON by plp-expressing OPCs raises the question of the relationship between these cells and the PDGFR $\alpha^{+}$OPCs (Richardson et al., 2000; Spassky et al., 2000). The existence of a population of OPCs that do not depend on PDGF receptor signaling for their survival, proliferation, and differentiation has recently been demonstrated in the mouse olfactory bulb (Spassky et al., 2001). Similarly, Fu et al., (2002) have shown that in the mouse spinal cord, in addition to PDGFR $\alpha^{+}$OPCs emerging from the pMN domain there is, in the $\mathrm{p} 3$ domain, a population of OPCs that do not express PDGFR $\alpha$. These findings suggest that the invasion of 


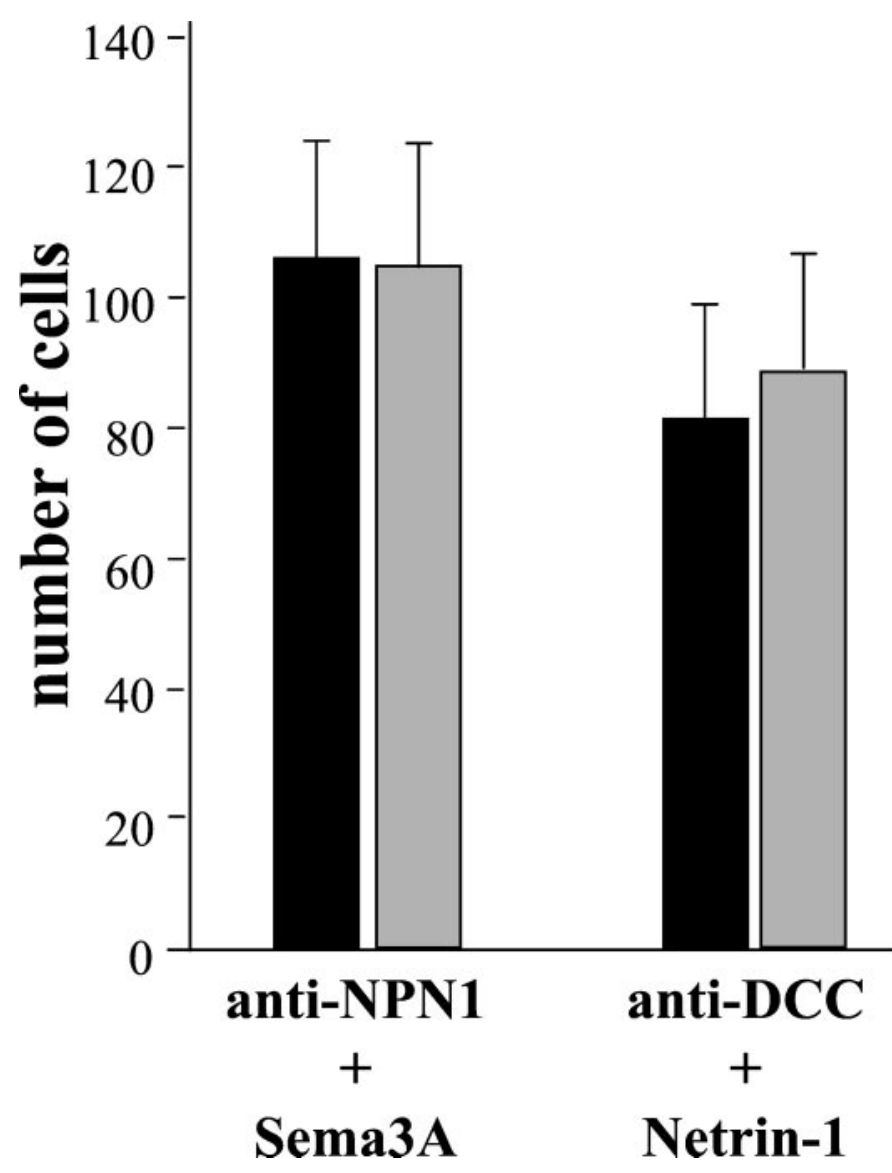

Figure 9. Blocking of neuropilin-1 and DCC change the migratory properties of OPCs. E16.5 mouse ON explants were cocultured with either Sema 3A or netrin-1-secreting cells, in the presence of blocking antibodies against either neuropilin-1 (NPN1) or DCC, respectively. Quantitation of the results was as indicated in Figure 5. Histogram shows the distribution of OPCs in the proximal (black columns) and distal (gray columns) quadrant of the ON explants. The repulsive action of Sema 3A as well as the attractive effect of netrin-1 (Fig. 5) are inhibited when their specific receptor is blocked with anti-neuropilin-1 or anti-DCC Ab, respectively.

the ON may occur in two waves: first, starting from E14.5, the $p l p^{+}$OPCs reported in this study, then around birth, the PDG$\mathrm{FRa}^{+}$OPCs. The existence of subpopulations of OPCs that depend or not on PDGF-A, explains the only partial and regiondependent loss of oligodendrocytes in the PDGF-A knock-out mouse (Fruttiger et al., 1999). In this respect, because the ON is populated by both populations of oligodendrocyte, it is surprising that the $\mathrm{ON}$ is one of the region that experienced the most severe loss of myelin in the PDGF-A knock-out mouse (Fruttiger et al., 1999). This apparent contradiction will require further investigations.

\section{OPC migratory properties correlate with expression of semaphorin and netrin receptors}

Using cultures of ON explants derived from E16.5 plp-shble-lacZ embryos, we have analyzed the molecular control of OPC migration. We provide evidence for a mitogenic effect, which may be trophic, of Sema 3 F on OPCs. We also show that Sema $3 \mathrm{~F}$ and netrin-1 are chemoattractive on OPCs. In addition, we confirm that Sema 3A exerts a chemorepulsive influence on OPCs (Sugimoto et al., 2001).

The neuropilins, a small family of type I transmembrane proteins that includes neuropilin-1 and neuropilin- 2, bind class 3 semaphorins with a high affinity (Chen et al., 1997; He and Tessier-Lavigne, 1997; Kolodkin et al., 1997). It has recently been reported that neuropilin-1 is expressed by mature oligodendrocytes and mediates the effect of Sema $3 \mathrm{~A}$ on the extension of oligodendrocyte processes (Ricard et al., 2000). We report that most OPCs in the ON (ON OPCs) also show neuropilin-1 expression and that anti-neuropilin-1-function blocking antibody inhibits the chemorepellent effect of Sema 3A. The neuropilin-1 receptor is therefore most probably mediating a repulsive response of OPCs to Sema 3A. In contrast to the effect of Sema 3A on neurons in culture (Bagnard et al., 2001), no cell death is promoted by this factor neither on mature oligodendrocytes (Ricard et al., 2000, 2001) nor on migrating OPCs (present study), suggesting that there are different transduction pathways mediated by neuropilin- 1 in the oligodendroglial lineage and in neurons. The ON OPCs also express neuropilin-2, and we show that in explants derived from neuropilin $2^{-1-}$-lac $Z$ mice, the chemoattractive effect of Sema $3 \mathrm{~F}$ on OPCs disappears. It is therefore likely that the attractive response of OPCs to Sema $3 \mathrm{~F}$ requires interaction with neuropilin-2.

DCC, a member of the Ig superfamily (Ig-CAMs), is a component of the receptor complex that mediates chemoattractive responses to netrin-1 (Keino-Masu et al., 1996). Here, we show that E18.5 ON OPCs express predominantly $D C C$, that $D C C^{+}$cells are localized in the expression domain of netrin-1, and that the chemoattractive effect of netrin-1 is blocked, in vitro, by antiDCC-function blocking antibody. It is worth noting that, according to the reports of Mehlen et al. (1998) and Forcet et al. (2001), the expression of netrin- 1 in the environment of $D C C^{+}$cells might protect OPCs from cell death. A second family of netrin-1 receptors, the unc5-related proteins, has been suggested to mediate chemorepulsive action of netrin-1 (Leonardo et al., 1997). Here we show that $u n c 5 H 1$ is also expressed by OPCs in the ON and that the number of unc5H1-expressing cells increases significantly between E18.5 and P5. This suggests that the effect of netrin-1 might be modulated by a developmentally regulated change in the expression of its receptors DCC and unc5H1. DCC receptor alone might be involved mainly at the time when OPCs enter the nerve, whereas, later in the course of development, DCC in cooperation with unc5H1 might participate in the signaling to stop migration. For instance, the strong expression of netrin- 1 in the retinal papilla, at the junction between the nerve and the retina, would prevent unc5H1-expressing OPCs to accumulate at the retinal end of the nerve and to enter the retina. The recent report of Sugimoto et al. (2001), that in the rat postnatal ON, netrin-1 is repulsive for OPCs supports this hypothesis.

Therefore, ON OPCs express a variety of receptors to class 3 semaphorins and netrin-1 factors, allowing multiple and adaptive responses to the environmental cues found in the course of their migration. This might be related to the presence of different types of OPCs, originating from different ventricular sources. Alternatively, it might indicate that, in the course of ON colonization, OPCs modulate their response to one secreted factor by changing the expression of its specific receptors.

\section{OPC migration correlates with semaphorin $3 A$, 3F, and netrin-1 expression}

The distribution of Sema 3A, Sema 3F, and netrin-1-secreting cells is shown in a schematic representation of the embryonic ON and its related structures (Fig. $10 H$ ). Sema $3 A$ is expressed around the $\mathrm{ON}$ at E16.5-E18.5. This pattern of Sema $3 A$ expression delineates a clear boundary between the outside and the inside of 
Figure 10. Expression patterns of Sema 3A, 3F, and netrin-1 in the $\mathrm{ON}$ and associated structures. Coronal cryosections across E18.5 retina $(A, C, G)$ and optic nerve $(B, D-F)$ were hybridized with digoxigeninlabeled Sema $3 A(A, B)$, netrin-1 $(C-F)$, and Sema $3 F$ $(G)$ antisense riboprobes. $A, B$, All along the nerve, perineural mesenchymal cells express Sema $3 A$ transcripts $(A$, arrow $) . C, D$, In contrast, the netrin- 1 transcripts are detected within the ON, in the optic papilla $(p$ in $C)$ and in the temporal quadrant of the nerve $(t$ in $D)$. E, Double-labeling with antisense netrin-1 riboprobe (blue) and anti-GFAP Ab (brown) shows that netrin-1 mRNAs are expressed by astrocytes (arrows). Inset in $E$ shows a higher magnification of a doublelabeled netrin- $1^{+} / \mathrm{GFAP}^{+}$cell. $F$, In the chiasmal segment of the ON, double labeling with netrin-1 riboprobe (blue) and anti-NG2 mAb (brown, arrows) shows an exclusion of the two markers at the cellular level. In the papilla, however, $\mathrm{NG}^{+}{ }^{+}$cells also express netrin-1 mRNA $(F$, inset $) . G$, Sema $3 F$ mRNAs are detected in the retina, including the photoreceptor layer and the retinal ganglion cell layer ( $G$, inset, arrow). No signal for Sema $3 F$ was detected along the ON. H, A schematic representation of the distribution pattern of cells expressing Sema $3 A$ (blue), netrin-1 (orange), and Sema $3 F$ ( purple). $n$, Nasal; $t$, temporal. Scale bar: $A-C, D, G, 60$ $\mu \mathrm{m} ; G$, inset, $30 \mu \mathrm{m} ; E, F, 17 \mu \mathrm{m} ; E, F$, insets, $9 \mu \mathrm{m}$.
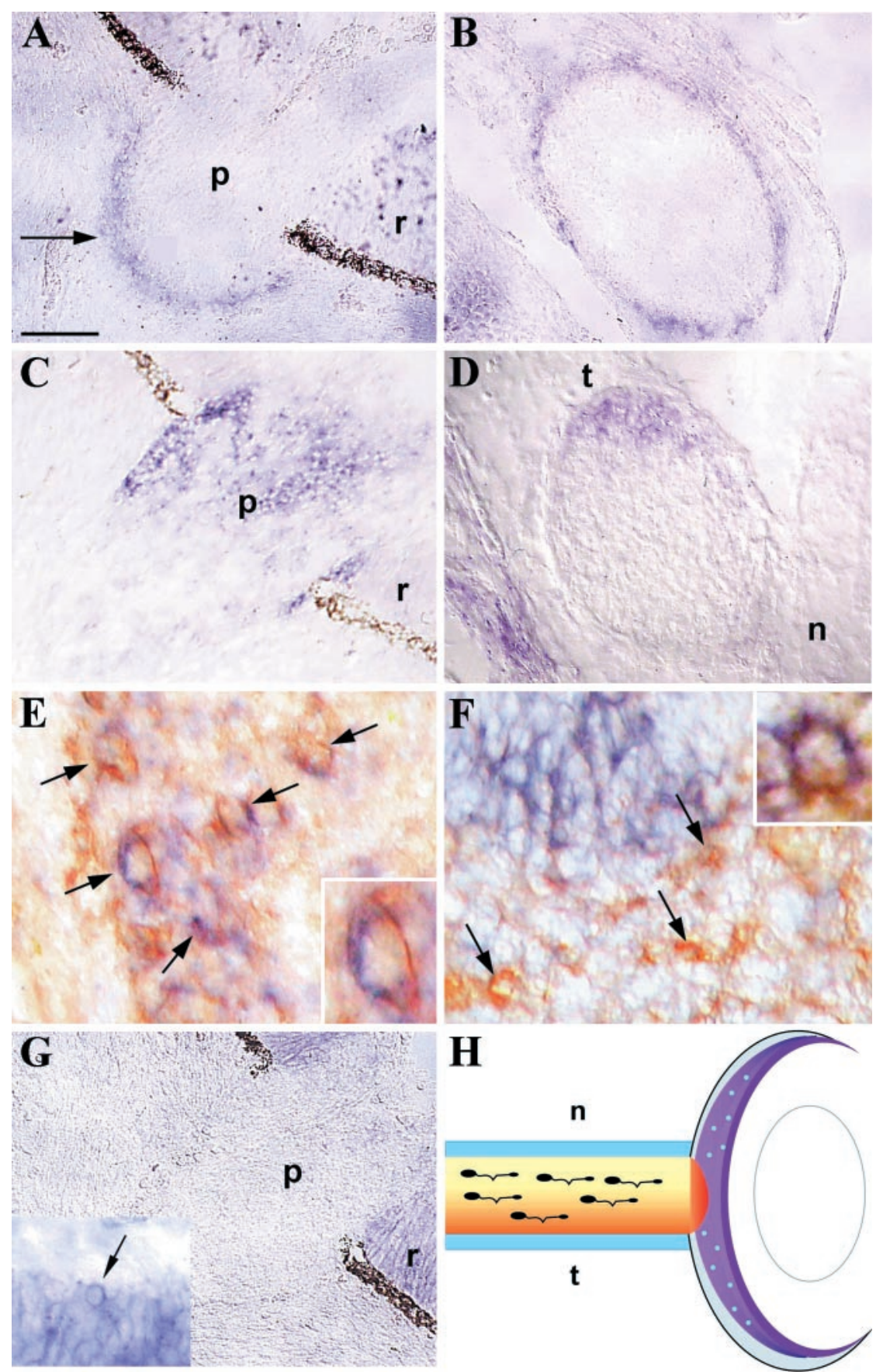

the nerve, which could force the OPCs to stay within the nerve and migrate along its length. The Sema $3 F$ transcripts are not detected around or inside the $\mathrm{ON}$, but are found in the retina, including the retinal ganglion cell layer. Sema $3 \mathrm{~F}$ might therefore be synthesized by retinal ganglion cells and transported along the axons, or be deposited along their path, to act as a chemoattractant on migrating ON OPCs. Netrin-1 is expressed all along the temporal quadrant and in the retinal end of the nerve. Because this factor provides a directional cue and facilitates cellular migration, notably by attracting cell processes far from the source (Yee et al., 1999), we suggest that the source of netrin-1 in the retinal papilla might guide OPCs toward the optic nerve end, and that in the chiasmal region, the temporal source of netrin- 1 might help OPCs to enter the nerve from the extramural stream of the ventral diencephalon. However, the absence of regionalization of OPCs in the nerve, together with the restricted distribution of netrin-1 to one quadrant of the ON, strengthen the hypothesis that subpopulations of ON OPCs might migrate following distinct routes in the nerve (Ono et al., 1997).

\section{Possible partners of chemotactic factors during OPC migration}

No alterations in the pattern of oligodendrocyte distribution have yet been reported in mice lacking either semaphorin $3 A$ (Taniguchi et al., 1997) or netrin-1 (Serafini et al., 1996). Nor has the loss of neuropilin-1 (Kitsukawa et al., 1997), neuropilin 2 (Chen et al., 2000; Giger et al., 2000), or DCC (Fazeli et al., 1997) resulted in any obvious defects in myelination. For the netrin-1, neuropilin-1, 
or DCC knock-out mice, the lack of data might be related to the fact that the animals die before the onset of myelination, impairing the observation of oligodendroglial anomalies. In addition, the factors probably operate in a mutually redundant manner while controlling the process of OPC migration, such that the loss of a single molecule has little impact on the outcome of the final migration pattern. Double mutant animals might therefore be needed to demonstrate in vivo effects of chemotactic factors and their receptors on OPC migration. Finally, the detection of OPCs in vivo has been greatly eased by the use of a reporter gene driven by the $p l p$ regulatory sequence. The introduction of such reporter into the genetic background of mutants will therefore facilitate the detection of changes in OPC migration. The corresponding interbreeding programs are underway in our laboratory.

The OPCs are axonophilic and the pattern of electrical firing in the nerve might provide additional information to migratory OPCs along the ON. The participation of adhesion molecules might also act in unison, as suggested by the interaction of neuropilin-1 with $\mathrm{Ng}-\mathrm{CAM} / \mathrm{L} 1$ in the corticospinal tract (Castellani et al., 2000). On the other hand, similarities with the polysialic acid-independent gliophilic radial migration of neural precursors (Rakic, 1974; Hatten, 1990) have been suggested (Ono et al., 1997), based on the fact that OPC migration was unaffected by the removal of polysialic acid associated with NCAM in the chick ON. The effort to identify secreted molecules controlling OPC migration might nevertheless be considered a priority, in the perspective of repair strategies of demyelinated zones. These factors could be manipulated to guide either endogenously generated or transplanted OPCs toward the demyelinated sites to improve remyelination of lesions in diseases like multiple sclerosis.

\section{REFERENCES}

Alcántara S, Ruiz M, De Castro F, Soriano E, Sotelo C (2000) Netrin 1 acts as an attractive or as a repulsive cue for distinct migrating neurons during the development of the cerebellar system. Development 127:1359-1372.

Armstrong RC, Harvath L, Dubois-Dalcq ME (1990) Type 1 astrocytes and oligodendrocyte-type 2 astrocyte glial progenitors migrate toward distinct molecules. J Neurosci Res 27:400-407.

Bagnard D, Vaillant C, Khuth ST, Dufay N, Lohrum M, Puschel AW, Belin MF, Bolz J, Thomasset N (2001) Semaphorin 3A-vascular endothelial growth factor- 165 balance mediates migration and apoptosis of neural progenitor cells by the recruitment of shared receptor. J Neurosci 21:3332-3341.

Bloch-Gallego E, Ezan F, Tessier-Lavigne M, Sotelo C (1999) Floor plate and netrin-1 are involved in the migration and survival of inferior olivary neurons. J Neurosci 19:4407-4420.

Castellani V, Chedotal A, Schachner M, Faivre-Sarrailh C, Rougon G (2000) Analysis of the L1-deficient mouse phenotype reveals cross-talk between Sema3A and L1 signaling pathways in axonal guidance. Neuron 27:237-249.

Chedotal A, Del Rio JA, Ruiz M, He Z, Borrell V, de Castro F, Ezan F, Goodman CS, Tessier-Lavigne M, Sotelo C, Soriano E (1998) Semaphorins III and IV repel hippocampal axons via two distinct receptors. Development 125:4313-4323.

Chen H, Chedotal A, He Z, Goodman CS, Tessier-Lavigne M (1997) Neuropilin-2, a novel member of the neuropilin family, is a high affinity receptor for the semaphorins Sema E and Sema IV but not Sema III. Neuron [Erratum (1997) 19:559] 19:547-559.

Chen H, Bagri A, Zupicich JA, Z ou Y, Stoeckli E, Pleasure SJ, Lowenstein DH, Skarnes WC, Chedotal A, Tessier-Lavigne M (2000) Neuropilin-2 regulates the development of selective cranial and sensory nerves and hippocampal mossy fiber projections. Neuron 25:43-56.

de Castro F, Hu L, Drabkin H, Sotelo C, Chedotal A (1999) Chemoattraction and chemorepulsion of olfactory bulb axons by different secreted semaphorins. J Neurosci 19:4428-4436.

Deiner MS, Sretavan DW (1999) Altered midline axon pathways and ectopic neurons in the developing hypothalamus of netrin-1- and DCCdeficient mice. J Neurosci 19:9900-9912.

Easter Jr SS0, Ross LS, Frankfurter A (1993) Initial tract formation in the mouse brain. J Neurosci 13:285-299.

Ebens A, Brose K, Leonardo ED, Hanson MG Jr, Bladt F, Birchmeier C, Barres BA, Tessier-Lavigne M (1996) Hepatocyte growth factor/scat- ter factor is an axonal chemoattractant and a neurotrophic factor for spinal motor neurons. Neuron 17:1157-1172.

Eickholt BJ, Mackenzie SL, Graham A, Walsh FS, Doherty P (1999) Evidence for collapsin-1 functioning in the control of neural crest migration in both trunk and hindbrain regions. Development 126:2181-2189.

Fanarraga ML, Sommer I, Griffiths IR (1995) O-2A progenitors of the mouse optic nerve exhibit a developmental pattern of antigen expression different from the rat. Glia 15:95-104.

Fazeli A, Dickinson SL, Hermiston ML, Tighe RV, Steen RG, Small CG, Stoeckli ET, Keino-Masu K, Masu M, Rayburn H, Simons J, Bronson RT, Gordon JI, Tessier-Lavigne M, Weinberg RA (1997) Phenotype of mice lacking functional Deleted in colorectal cancer (Dcc) gene. Nature 386:796-804.

Forcet C, Ye X, Granger L, Corset V, Shin H, Bredesen DE, Mehlen P (2001) The dependence receptor DCC (deleted in colorectal cancer) defines an alternative mechanism for caspase activation. Proc Natl Acad Sci USA 98:3416-3421.

Fruttiger M, Karlsson L, Hall AC, Abramsson A, Calver AR, Bostrom H, Willetts K, Bertold CH, Heath JK, Betsholtz C, Richardson WD (1999) Defective oligodendrocyte development and severe hypomyelination in PDGF-A knockout mice. Development 126:457-467.

Fu H, Qi Y, Tan M, Cai J, Takebayashi H, Nakafuku M, Richardson W, Qiu M (2002) Dual origin of spinal oligodendrocyte progenitors and evidence for the cooperative role of Olig2 and Nkx2.2 in the control of oligodendrocyte differentiation. Development 129:681-693.

Garcion E, Faissner A, ffrench-Constant C (2001) Knockout mice reveal a contribution of the extracellular matrix molecule tenascin-C to neural precursor proliferation and migration. Development 128:2485-2496.

Giger RJ, Cloutier JF, Sahay A, Prinjha RK, Levengood DV, Moore SE, Pickering S, Simmons D, Rastan S, Walsh FS, Kolodkin AL, Ginty DD, Geppert M (2000) Neuropilin-2 is required in vivo for selective axon guidance responses to secreted semaphorins. Neuron 25:29-41.

Hatten ME (1990) Riding the glial monorail: a common mechanism for glial-guided neuronal migration in different regions of the developing mammalian brain. Trends Neurosci 13:179-184.

He Z, Tessier-Lavigne M (1997) Neuropilin is a receptor for the axonal chemorepellent Semaphorin III. Cell 90:739-751.

Keino-Masu K, Masu M, Hinck L, Leonardo ED, Chan SS, Culotti JG, Tessier-Lavigne M (1996) Deleted in Colorectal Cancer (DCC) encodes a netrin receptor. Cell 87:175-185.

Kiernan BW, Gotz B, Faissner A, ffrench-Constant C (1996) Tenascin-C inhibits oligodendrocyte precursor cell migration by both adhesiondependent and adhesion-independent mechanisms. Mol Cell Neurosci 7:322-335.

Kitsukawa T, Shimizu M, Sanbo M, Hirata T, Taniguchi M, Bekku Y, Yagi T, Fujisawa H (1997) Neuropilin-semaphorin III/D-mediated chemorepulsive signals play a crucial role in peripheral nerve projection in mice. Neuron 19:995-1005.

Kolodkin AL, Levengood DV, Rowe EG, Tai YT, Giger RJ, Ginty DD (1997) Neuropilin is a semaphorin III receptor. Cell 90:753-762.

Leonardo ED, Hinck L, Masu M, Keino-Masu K, Ackerman SL, TessierLavigne M (1997) Vertebrate homologues of C. elegans UNC-5 are candidate netrin receptors. Nature 386:833-838.

Lima FR, Gervais A, Colin C, Izembart M, Neto VM, Mallat M (2001) Regulation of microglial development: a novel role for thyroid hormone. J Neurosci 21:2028-2038.

Lumsden AG, Davies AM (1983) Earliest sensory nerve fibres are guided to peripheral targets by attractants other than nerve growth factor. Nature 306:786-788.

Lumsden AG, Davies AM (1986) Chemotropic effect of specific target epithelium in the developing mammalian nervous system. Nature 323:538-539.

Manitt C, Colicos MA, Thompson KM, Rousselle E, Peterson AC, Kennedy TE (2001) Widespread expression of netrin-1 by neurons and oligodendrocytes in the adult mammalian spinal cord. J Neurosci 21:3911-3922.

Marin O, Yaron A, Bagri A, Tessier-Lavigne M, Rubenstein JL (2001) Sorting of striatal and cortical interneurons regulated by semaphorinneuropilin interactions. Science 293:872-875.

Mehlen P, Rabizadeh S, Snipas SJ, Assa-Munt N, Salvesen GS, Bredesen DE (1998) The DCC gene product induces apoptosis by a mechanism requiring receptor proteolysis. Nature 395:801-804.

Messersmith EK, Leonardo ED, Shatz CJ, Tessier-Lavigne M, Goodman CS, Kolodkin AL (1995) Semaphorin III can function as a selective chemorepellent to pattern sensory projections in the spinal cord. Neuron 14:949-959.

Mi H, Barres BA (1999) Purification and characterization of astrocyte precursor cells in the developing rat optic nerve. J Neurosci 19:1049-1061.

Milner R, Ffrench-Constant C (1994) A developmental analysis of oligodendroglial integrins in primary cells: changes in alpha v-associated beta subunits during differentiation. Development 120:3497-3506.

Milner R, Anderson HJ, Rippon RF, McKay JS, Franklin RJ, Marchionni MA, Reynolds R, Ffrench-Constant C (1997) Contrasting effects of 
mitogenic growth factors on oligodendrocyte precursor cell migration. Glia 19:85-90.

Niehaus A, Stegmuller J, Diers-Fenger M, Trotter J (1999) Cell-surface glycoprotein of oligodendrocyte progenitors involved in migration. J Neurosci 19:4948-4961.

Olivier C, Cobos I, Perez Villegas EM, Spassky N, Zalc B, Martinez S, Thomas JL (2001) Monofocal origin of telencephalic oligodendrocytes in the anterior entopeduncular area of the chick embryo. Development 128:1757-1769.

Ono K, Yasui Y, Rutishauser U, Miller RH (1997) Focal ventricular origin and migration of oligodendrocyte precursors into the chick optic nerve. Neuron 19:283-292.

Payne HR, Lemmon V (1993) Glial cells of the O-2A lineage bind preferentially to $\mathrm{N}$-cadherin and develop distinct morphologies. Dev Biol 159:595-607.

Perez Villegas EM, Olivier C, Spassky N, Poncet C, Cochard P, Zalc B, Thomas JL, Martinez S (1999) Early specification of oligodendrocytes in the chick embryonic brain. Dev Biol 216:98-113.

Raff MC, Miller RH, Noble M (1983) A glial progenitor cell that develops in vitro into an astrocyte or an oligodendrocyte depending on culture medium. Nature 303:390-396.

Rakic P (1974) Neurons in rhesus monkey visual cortex: systematic relation between time of origin and eventual disposition. Science 183:425-427.

Raper JA (2000) Semaphorins and their receptors in vertebrates and invertebrates. Curr Opin Neurobiol 10:88-94.

Ricard D, Stankoff B, Bagnard D, Aguera M, Rogemond V, Antoine JC, Spassky N, Zalc B, Lubetzki C, Belin MF, Honnorat J (2000) Differential expression of collapsin response mediator proteins (CRMP/ ULIP) in subsets of oligodendrocytes in the postnatal rodent brain. Mol Cell Neurosci 16:324-337.

Ricard D, Rogemond V, Charrier E, Aguera M, Bagnard D, Belin MF, Thomasset N, Honnorat J (2001) Isolation and expression pattern of human Unc-33-like phosphoprotein 6/collapsin response mediator protein 5 (Ulip6/CRMP5): coexistence with Ulip2/CRMP2 in Sema3asensitive oligodendrocytes. J Neurosci 21:7203-7214.

Richardson WD, Smith HK, Sun T, Pringle NP, Hall A, Woodruff R (2000) Oligodendrocyte lineage and the motor neuron connection. Glia 29:136-142.

Schneider S, Bosse F, D’Urso D, Muller HW, Sereda MW, Nave KA, Niehaus A, Kempf T, Schnolzer M, Trotter J (2001) The AN2 protein is a novel marker for the Schwann cell lineage expressed by immature and nonmyelinating Schwann cells. J Neurosci 21:920-933.

Serafini T, Kennedy TE, Galko MJ, Mirzayan C, Jessell TM, TessierLavigne M (1994) The netrins define a family of axon outgrowthpromoting proteins homologous to C. elegans UNC-6. Cell 78:409-424.
Serafini T, Colamarino SA, Leonardo ED, Wang H, Beddington R, Skarnes WC, Tessier-Lavigne M (1996) Netrin-1 is required for commissural axon guidance in the developing vertebrate nervous system. Cell 87:1001-1014.

Skoff RP (1990) Gliogenesis in rat optic nerve: astrocytes are generated in a single wave before oligodendrocytes. Dev Biol 139:149-168.

Small RK, Riddle P, Noble M (1987) Evidence for migration of oligodendrocyte-type-2 astrocyte progenitor cells into the developing rat optic nerve. Nature 328:155-157.

Sommer I, Schachner M (1981) Monoclonal antibodies (O1 to O4) to oligodendrocyte cell surfaces: an immunocytological study in the central nervous system. Dev Biol 83:311-327.

Spassky N, Goujet-Zalc C, Parmantier E, Olivier C, Martinez S, Ivanova A, Ikenaka K, Macklin W, Cerruti I, Zalc B, Thomas JL (1998) Multiple restricted origin of oligodendrocytes. J Neurosci 18:8331-8343.

Spassky N, Goujet-Zale C, Olivier C, Martinez S, Thomas JL, Zale B (2000) Single or multiple origin of oligodendrogliol lineages: a controversy. Glia 29:143-148.

Spassky N, Heydon K, Mangatal A, Jankovsky A, Olivier C, Goujet-Zalc C, Thomas J-L, Zalc B (2001) Sonic hedgehog dependent emergence of oligodendrocytes in the telencephalon: Evidence for a source of oligodendrocytes in the olfactory bulb independent on PDGFRa signaling. Development 218:4993-5004.

Sugimoto Y, Taniguchi M, Yagi T, Akagi Y, Nojyo Y, Tamamaki N (2001) Guidance of glial precursor cell migration by secreted cues in the developing optic nerve. Development 128:3321-3330.

Szele FG, Cepko CL (1998) The dispersion of clonally related cells in the developing chick telencephalon. Dev Biol 195:100-113.

Taniguchi M, Yuasa S, Fujisawa H, Naruse I, Saga S, Mishina M, Yagi T (1997) Disruption of semaphorin III/D gene causes severe abnormality in peripheral nerve projection. Neuron 19:519-530.

Wallace VA, Raff MC (1999) A role for Sonic hedgehog in axonto-astrocyte signalling in the rodent optic nerve. Development 126:2901-2909.

Wang C, Rougon G, Kiss JZ (1994) Requirement of polysialic acid for the migration of the O-2A glial progenitor cell from neurohypophyseal explants. J Neurosci 14:4446-4457.

Yee KT, Simon HH, Tessier-Lavigne M, O'Leary DM (1999) Extension of long leading processes and neuronal migration in the mammalian brain directed by the chemoattractant netrin-1. Neuron 24:607-622.

Yu WP, Collarini EJ, Pringle NP, Richardson WD (1994) Embryonic expression of myelin genes: evidence for a focal source of oligodendrocyte precursors in the ventricular zone of the neural tube. Neuron $12: 1353-1362$. 